\title{
Fatigue strength of austempered ductile iron-to-steel dissimilar arc-welded joints
}

\author{
G. Meneghetti ${ }^{1}$ (D) A. Campagnolo ${ }^{1} \cdot$ D. Berto ${ }^{1} \cdot$ E. Pullin $^{1} \cdot$ S. Masaggia ${ }^{2}$
}

Received: 15 October 2019 / Accepted: 23 December 2020 / Published online: 22 February 2021

(C) The Author(s) 2021

\begin{abstract}
Nowadays, the use of different classes of materials in the same structure is increased to keep pace with innovation and high structural performances. In this context, structural components made of different materials need to be joined together and a possible solution is given by arc welding. Dissimilar welded joints must often be able to withstand fatigue loads; however, Design Standards provide fatigue strength categories only for homogeneous welded joints. The aim of the present paper is to compare the fatigue behaviour of EN-GJS-1050 austempered ductile iron-to-S355J2 steel dissimilar joints to the categories of the corresponding homogeneous steel welded joints, as suggested in International Standards and Recommendations. For this purpose, experimental fatigue tests were performed on a selection of dissimilar welded details. First, the microstructure was identified by metallographic analysis; micro-hardness measurements were collected and residual stress profiles were obtained by using the X-ray diffraction technique on a selection of joints. Misalignments were quantified for all specimens. Then, experimental fatigue tests have been performed on a number of joint geometries subject to axial or bending fatigue loadings and tested in the as-welded conditions. The fracture surfaces of the joints have been analysed to locate fatigue crack nucleation sites.
\end{abstract}

Keywords Dissimilar welded joints $\cdot$ Fatigue strength $\cdot$ Austempered ductile iron $\cdot$ Arc welding $\cdot$ FAT value

\section{Introduction}

In several industries, the trend for more optimal, lightweight and high-performance products leads to the adoption of hybrid structures. The combination of various materials allows taking advantage of their different properties for integrating an increased number of functions in each part. This approach is mainly adopted in the field of aeronautics, automotive, tooling, power generation and marine applications.

Recommended for publication by Commission XIII - Fatigue of Welded Components and Structures

G. Meneghetti

giovanni.meneghetti@unipd.it

1 Department of Industrial Engineering, University of Padova, Via Venezia, 1, 35131 Padua, Italy

2 Zanardi Fonderie Spa, Via Nazionale 3, 37046, Minerbe, Verona, Italy
Structural components made of dissimilar materials have to be joined together, but the joining processes can, on the other hand, be challenging when materials present different chemical, mechanical, thermal or electrical properties. The potential incompatibility can create problems not only for the joining process itself, but also for the structural integrity of the joints during the life cycle of the product. The main advantages and challenges of joining dissimilar materials have recently been reviewed by Martinsen et al. [1].

In the technical literature, many papers have been dedicated to explore different welding techniques for joining dissimilar materials: the most widely adopted is the friction welding [2-9], together with arc welding [10-16] and laser welding $[17,18]$, but also other techniques are employed, such as resistance spot welding [19, 20] and magnetic pulse welding [21]. In the context of arc welding, joining austempered ductile iron (ADI) to dissimilar structural steel allows the mechanical response of structural components to be improved, combining weight reduction and net-to-shape geometry at the same time. Indeed, ADI offers very good static, impact, fatigue performances and moderate wear resistance. On top of that, 
Fig. 1 ADI 1050 microstructure, relevant w.t. $25 \mathrm{~mm}$. a As cast, before austempering $(\times 100)$, matrix equivalent to ductile iron JS/700-2. b After austempering $(\times 500)$

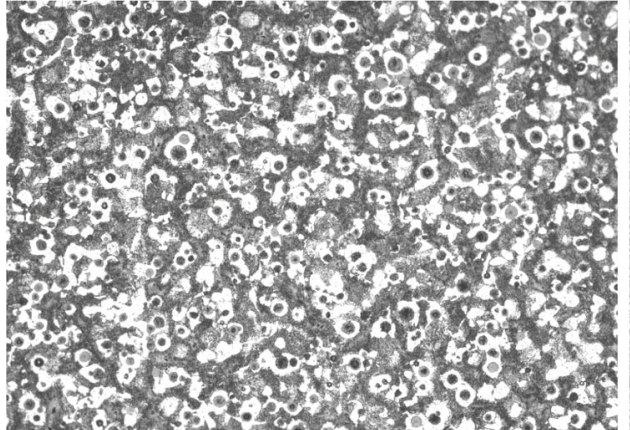

a)

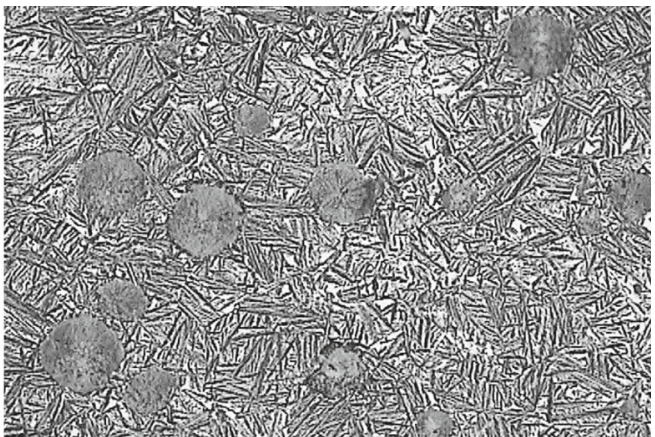

b) its optimum castability enables to obtain complex geometries with great lightweight characteristics. This leads to the optimization of mass distribution based on both actual stiffness and required load levels. Therefore, the use of steel can be limited where needed or mandatory.

Dissimilar welded joints must also sustain high cyclic loads under service conditions. Concerning fatigue life prediction of welded joints, different design criteria are available in International Standards and Recommendations [22-24]. The easiest way to evaluate the fatigue strength of a welded structure is to compare the nominal stress with an appropriate design category of the joint, defined by the geometry and loading condition. This method is known as the nominal stress approach. Even though the latter is the most widespread, approaches like the hot-spot stress, the notch stress and the Linear Elastic Fracture Mechanics can be employed. However, International Standards and Recommendations [22-24] provide fatigue strength categories based on the nominal stress approach only for homogeneous welded joints, made of structural steels or aluminium alloys, and not for dissimilar joints. Several papers in the recent literature have addressed the analysis of the fatigue behaviour of dissimilar joints made of different grades of structural steels $[2,3,10-15,17]$, different series of aluminium alloys [4], a steel and an aluminium alloy [6-9] or other metallic materials welded together $[5,19]$. However, to the best of authors' knowledge, a quantitative analysis of the fatigue behaviour of dissimilar ADI-to-steel welded joints is lacking in the technical literature and in all International Standards and Recommendations $[22,24]$. Thus, in the present investigation, experimental tests have been carried out to derive the fatigue strength of austempered ductile iron (EN-GJS1050)-to-steel (S355J2) dissimilar arc-welded joints. Afterwards, the aims of the present paper are:

- to identify the microstructure of post-weld materials in ADI-steel joints by metallographic analysis, to measure specimens misalignment and to define micro-hardness and residual stresses profiles;

- to carry out experimental fatigue tests on ADI-steel joints on some typical welded details and to analyse the fracture surfaces of the joints to identify the fatigue crack initiation locations;

- to derive the fatigue strength categories of the tested welded details and to compare them with the categories
Fig. 2 Geometries of austempered ductile iron-to-steel dissimilar arc-welded joints. a partial-penetration butt-welded joints. b1 full-penetration buttwelded joints. b2 full-penetration butt welded joints. $\mathbf{c}$ non-loadcarrying fillet-welded transverse stiffener joints

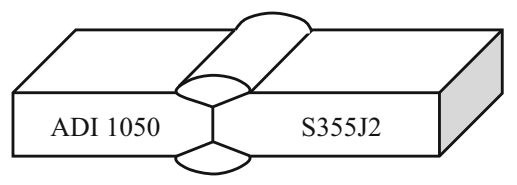

(a)

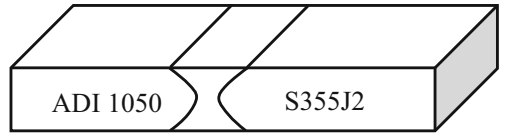

(b2):

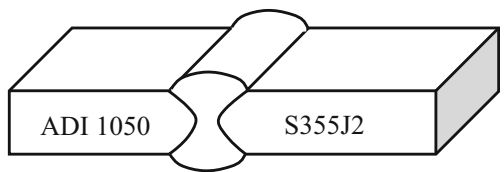

(b1):

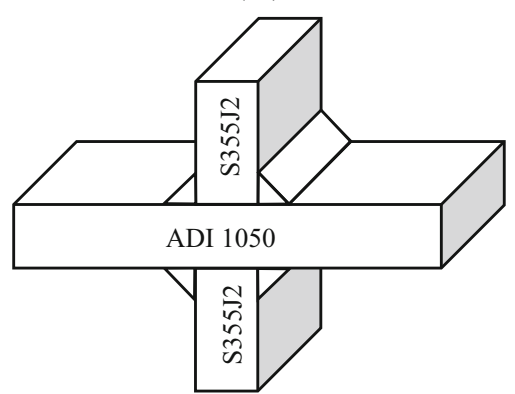

(c) 


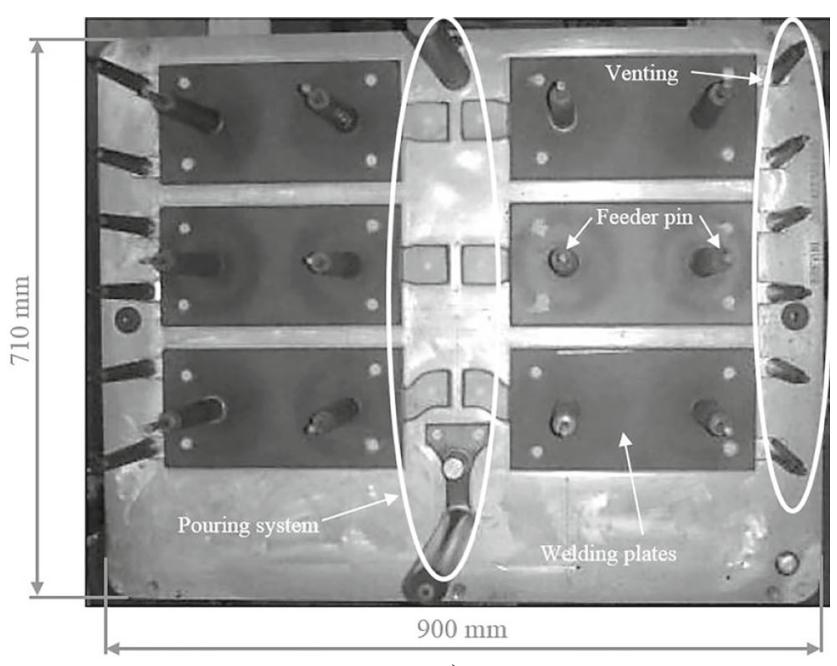

a)

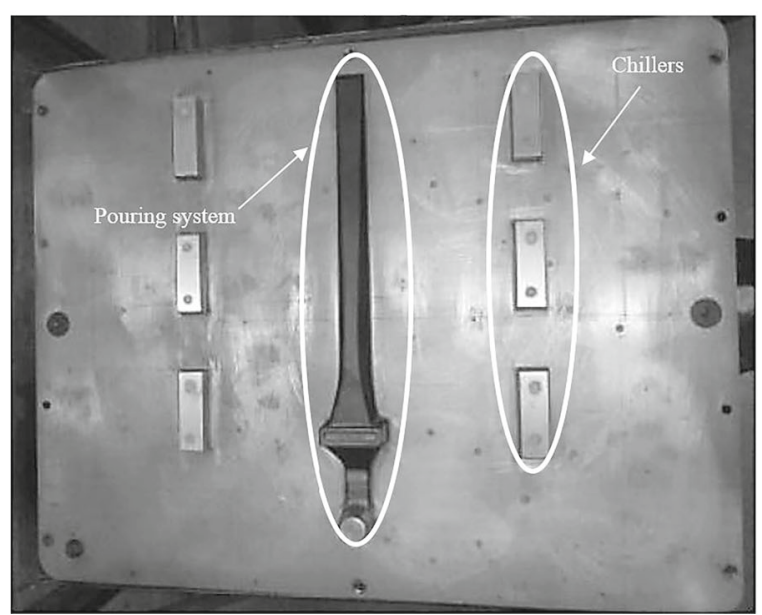

b) provided by Standards and Recommendations for homogeneous steel welded joints.

\section{Testing programme}

S355J2 EN10025-2 hot rolled construction steel (S355J2) is commonly used in structural applications such as freight cars, trucks, cranes and excavators, while ISO 17804 JS/1050-6 Austempered Ductile Iron (ADI 1050) typical applications are for earth movement undercarriage components, passenger vehicles and freight cars' suspension parts, axles, power transmission components, crankshafts, etc. ADI 1050 derives from a heat-treated low alloyed Pearlitic-Ferritic Ductile Iron, cast after a special preconditioning of the metal bath. In the cast material, carbon is typically arranged in spheroidal graphite particles (Fig. 1a). The 'Austempering', i.e. the isothermal heat treatment of spheroidal graphite cast iron, has two main phases: first, heating the casting at $900{ }^{\circ} \mathrm{C}$; then, cooling it in salt bath having constant temperature of 350 ${ }^{\circ} \mathrm{C}$, at a cooling rate able to promote the formation of 'Ausferrite'.

The new matrix is called 'Ausferritic' and its microstructure mainly consists of retained austenite and acicular ferrite (Fig. 1b). This gives excellent mechanical properties to the ADI 1050, being comparable with those of a 42CrMo4Q\&T steel material.

Figure 2 shows the welded details fatigue tested in the present paper, which include:

Fig. 3 Experimental pattern plate for cast iron plates. a Top, b bottom

Fig. 4 ADI 1050 BoP without filler material, optimum microstructure after welding
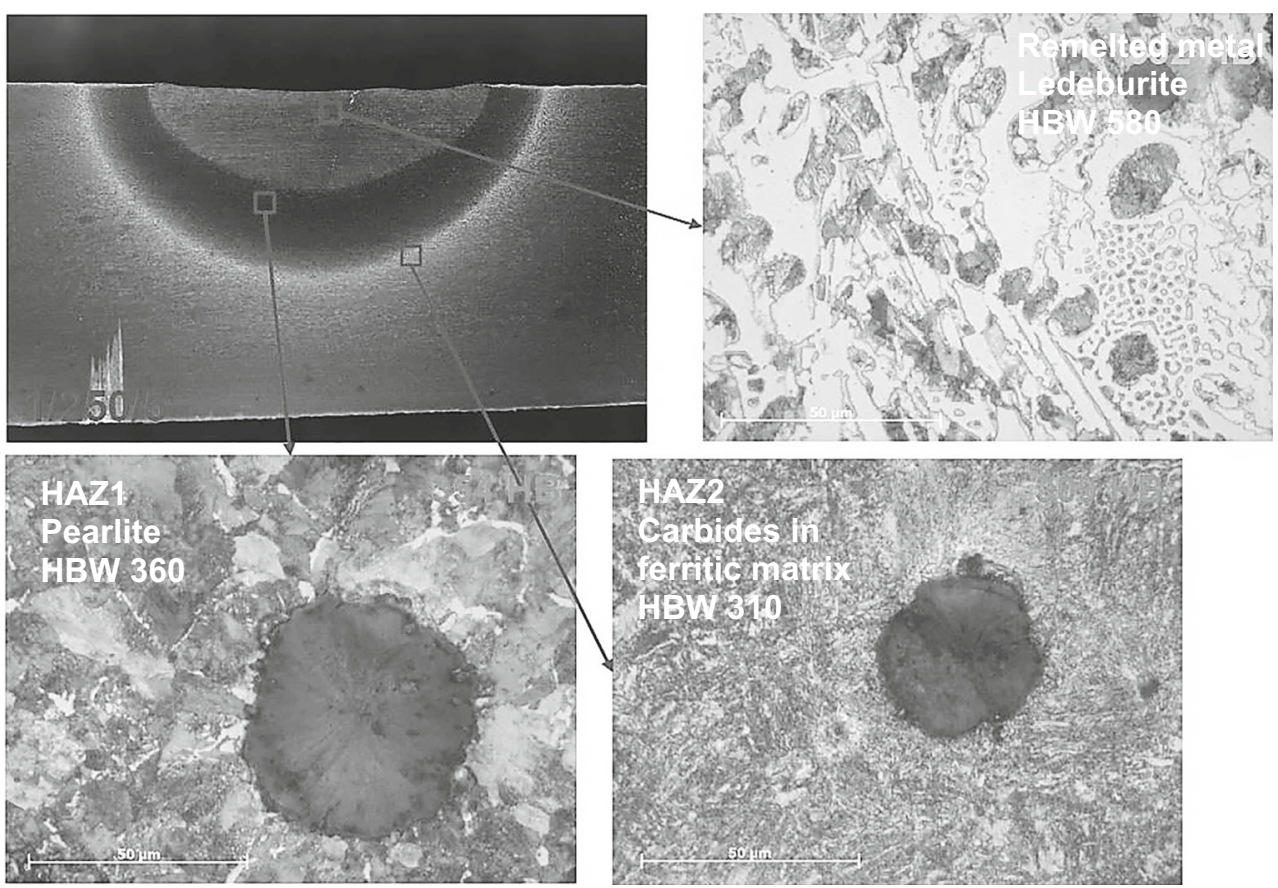
Fig. 5 ADI 1050 BoP HAZ1, trend according to $\mathrm{HI}$ and $\mathrm{Tp}$

Fig. 6 ADI 1050 BoP HAZ2, trend according to $\mathrm{HI}$ and $\mathrm{Tp}$

Table 1 ADI $1050 \mathrm{BoP}$ with filler material, GMAW welding parameters

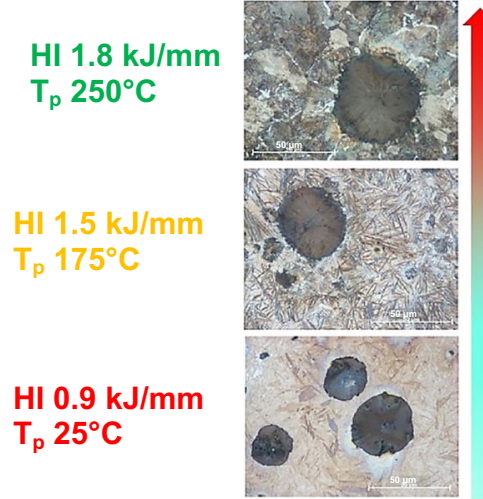

$\mathrm{HI}, \mathrm{T}_{\mathrm{p}}$

354 HB

Graphite nodules in pearlitic matrix

Graphite nodules in martensitic

$435 \mathrm{HB}$ matrix + residual austenite plates

Graphite nodules in martensitic matrix

$643 \mathrm{HB}$
$\mathrm{T}_{\mathrm{p}} 250^{\circ} \mathrm{C}$

HI $1.5 \mathrm{~kJ} / \mathrm{mm}$

$\mathrm{T}_{\mathrm{p}} 175^{\circ} \mathrm{C}$

HI $0.9 \mathrm{~kJ} / \mathrm{mm}$

$\mathrm{T}_{\mathrm{p}} 25^{\circ} \mathrm{C}$

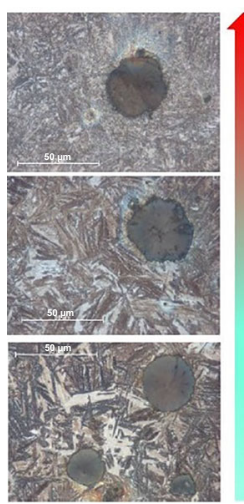

$\mathrm{HI}, \mathrm{T}_{\mathrm{p}}$

Graphite nodules in ferritic matrix + carbides

Graphite nodules in bainitic matrix

Graphite nodules in bainitic matrix

\begin{tabular}{lllll}
\hline Mode of metal transfer & Current [A] & Voltage [V] & $\begin{array}{l}\text { Travel speed } \\
{[\mathrm{mm} / \mathrm{min}]}\end{array}$ & $\begin{array}{l}\text { Heat input } \\
{[\mathrm{kJ} / \mathrm{mm}]}\end{array}$ \\
\hline PULSED ARC (P) & $180 \div 200$ & $29.7 \div 30.3$ & 260 & $1.2 \div 1.3$ \\
SHORT ARC (D) & $175 \div 180$ & $22.8 \div 23.0$ & 260 & $0.8 \div 0.9$ \\
Preheat temperature & & $300{ }^{\circ} \mathrm{C}$ & & \\
\hline
\end{tabular}

Table 2 GMAW welding parameters adopted for specimens

Mode of metal transfer Welding position Torche angle direction Filler material

\begin{tabular}{|c|c|}
\hline & $\begin{array}{l}\text { UNI EN } \\
\text { ISO } 6947 \text { PA }\end{array}$ \\
\hline
\end{tabular}

Preheat temperature

Interpass temperature

Shielding

$\begin{array}{llll}\begin{array}{l}\text { Current and } \\ \text { polarity [A] }\end{array} & \text { Voltage [V] } & \begin{array}{l}\text { Travel speed } \\ {[\mathrm{mm} / \mathrm{min}]}\end{array} & \begin{array}{l}\text { Heat input } \\ {[\mathrm{kJ} / \mathrm{mm}]}\end{array} \\ \begin{array}{l}\text { CCPI } \\ \text { 120-130 }\end{array} & 24-25 & 220-340 & 0.41-0.71 \\ & & \\ & & \\ \text { 80-20), flow rate } 16-18 \mathrm{lt} / \mathrm{min}\end{array}$

Current and Voltage [V] Travel speed Heat input

S C NiFe-2 EN ISO 1071 CCPI
$\varnothing 1.2 \mathrm{~mm}$
EN 13916-TC $200{ }^{\circ} \mathrm{C}$
EN 13916-TC $250{ }^{\circ} \mathrm{C}$
ISO $14175 \mathrm{M} 21\left(\mathrm{Ar}-\mathrm{CO}_{2} 80-20\right)$, flow rate $16-18 \mathrm{lt} / \mathrm{min}$


Table 3 Specimens' geometry and preparation

\section{Macrograph \& HBW position}

Type of joint \& PT results

HAZ ADI 1050 \& HAZ S355J2 micrographs

(A) partial-penetration butt welded joint
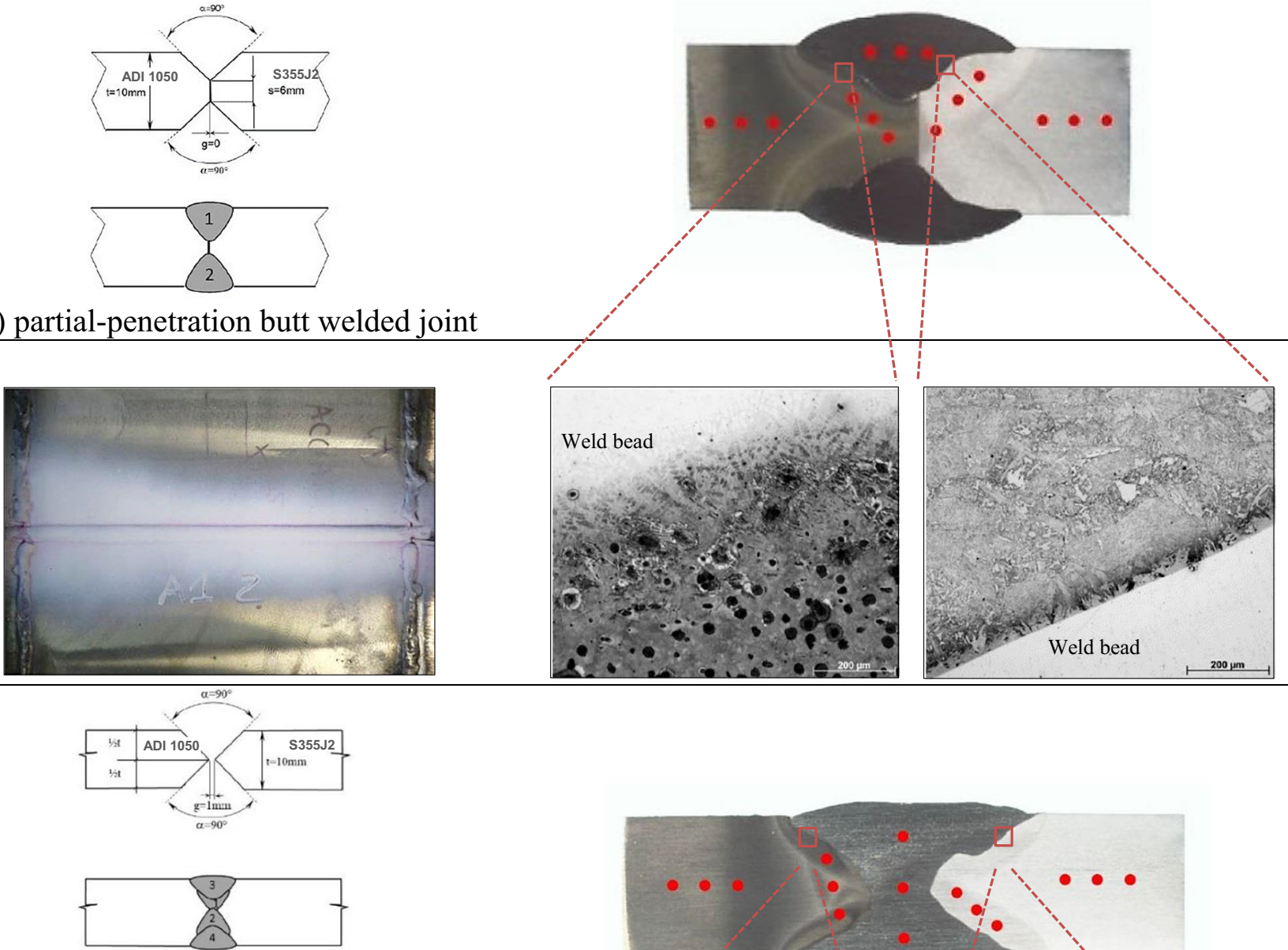

(B1) full penetration butt welded joints

(B2) full penetration butt welded joints,
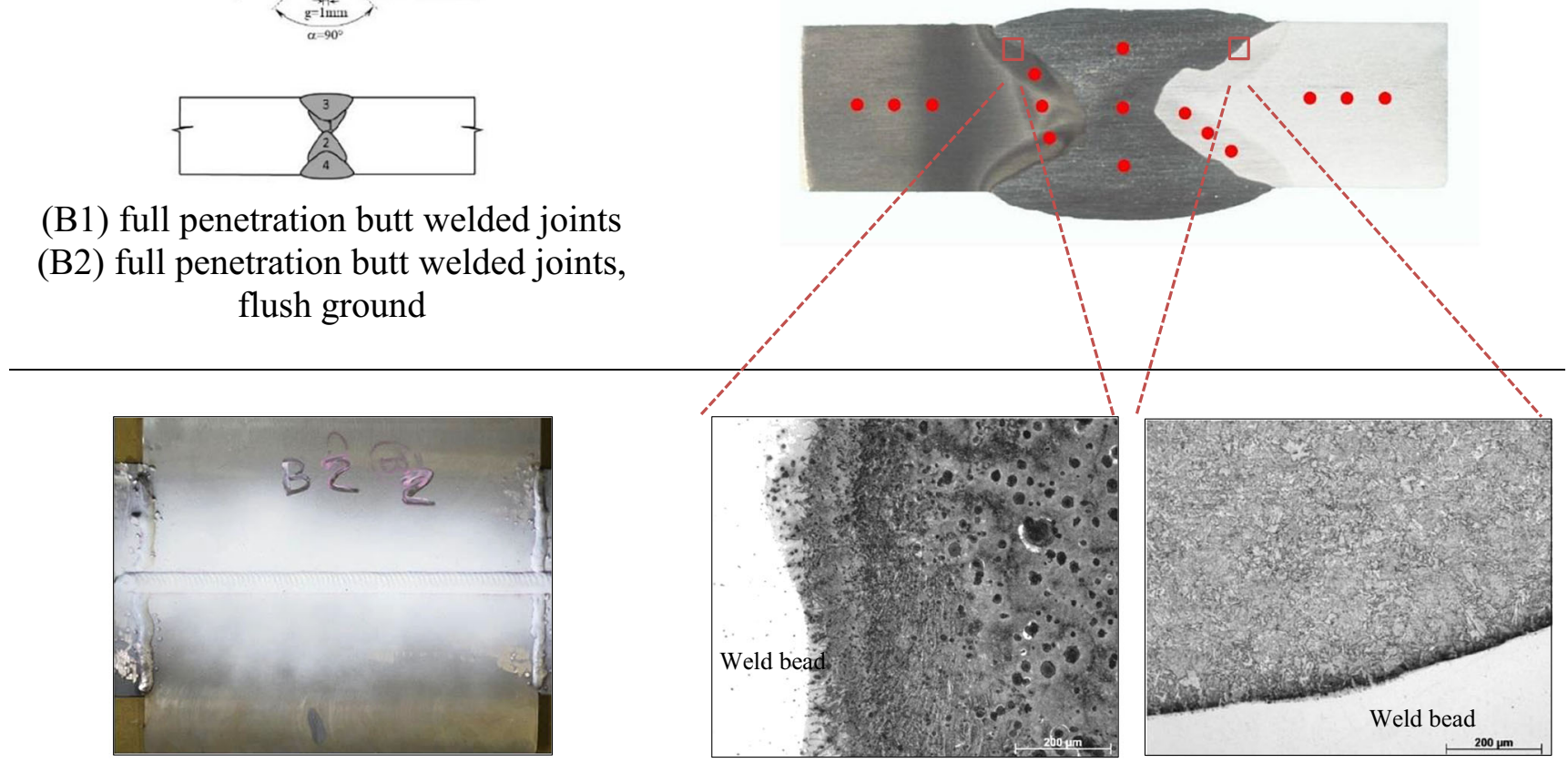


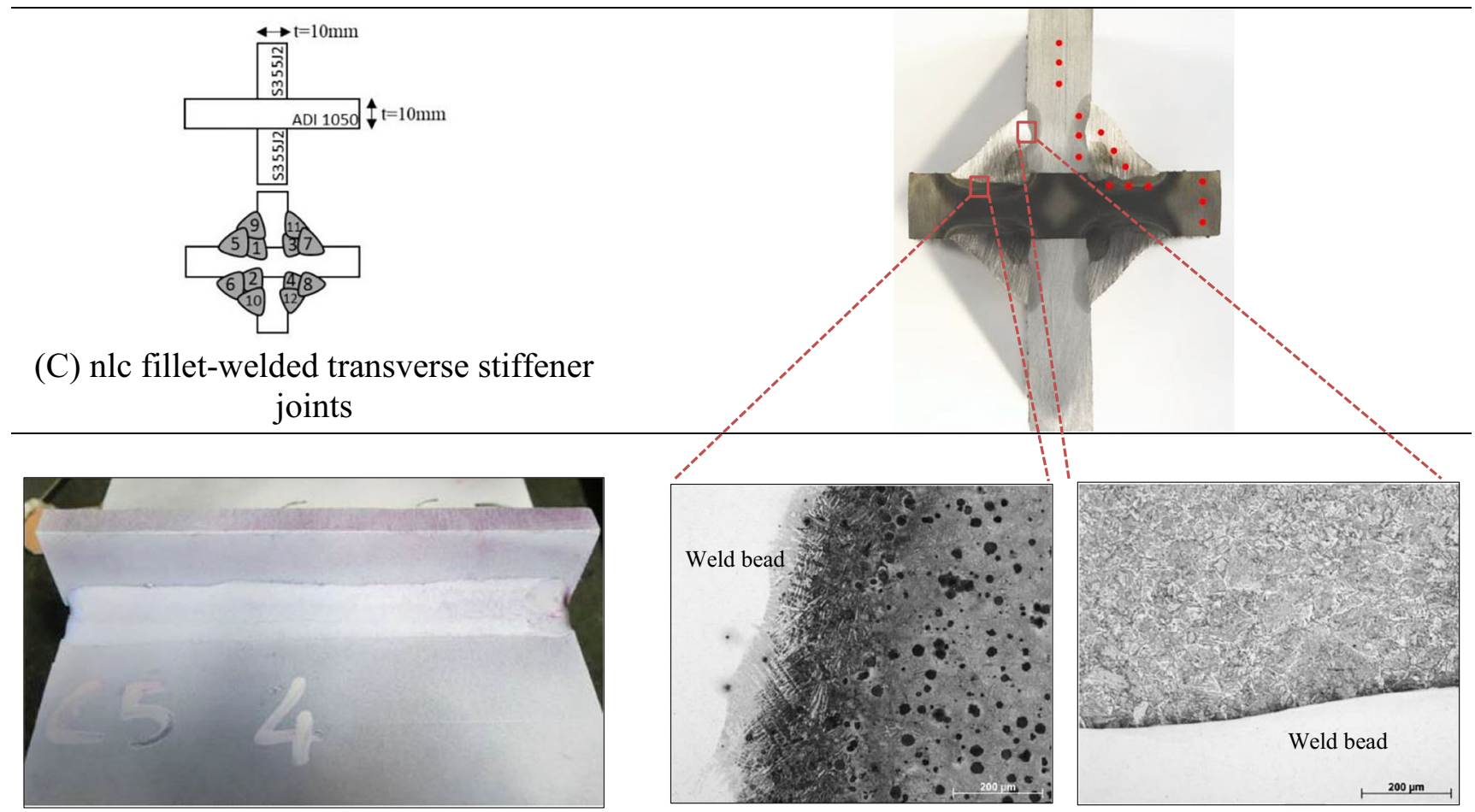

- Series A: partial-penetration butt welded joints;

- Series B1: full-penetration butt welded joints;

- Series B2: full-penetration butt welded joints, flush ground;

- Series C: non-load-carrying (nlc) fillet-welded transverse stiffener joints.

\section{Preparation of welded specimens}

All specimens were realised cutting $300 \times 150 \times 12 \mathrm{~mm}$ plates. Ductile iron plates have been poured by Zanardi Fonderie S.p.A. in horizontal greensand moulds printed using a proper experimental pattern plate (Fig. 3). After that, plates were sand cleaned after shakeout, austempered to material grade ADI 1050 and milled to the final thickness of $10 \mathrm{~mm}$.

Steel plates, having the same initial dimensions, have been obtained from commercial hot rolled plates and milled to $10-$ mm thickness.

All plates were grinded, brushed and properly clamped by means of tack welded fixture bracket with the aim of minimising welding distortions. Final specimen's dimensions were obtained by cutting after welding. 'Istituto Italiano della Saldatura' (IIS) performed all welding operations.

ADI 1050 was characterised by ultimate strength $R_{\mathrm{m}}=1100$ $\mathrm{MPa}$, yield strength $R_{\mathrm{p} 02}=920 \mathrm{MPa}$, Brinell hardness HBW $=$
350-380 and elongation at fracture $A_{5}=8 \%$, previous mechanical properties being obtained from specimens cut from the plates. S355J2 mechanical properties according to EN10025-2 are as follows: $R_{\mathrm{m} \min }=470 \mathrm{MPa}, R_{\mathrm{p} 02 \min }=$ $355 \mathrm{MPa}, \mathrm{HBW}=160-180$ and $A_{5 \min }=22 \%$.

\subsection{Welding process setup by means of beads on plate}

Preliminary dummy tests were carried out on 20-mm-thick ADI 1050 plates, in order to set up welding parameters. First of all, beads on plate (BoP) were created using fully mechanised TIG-welding process without filler material for tuning $\mathrm{HI}$ (heat input) and $\mathrm{Tp}$ (preheat temperature): HI range was increased up to $2.2 \mathrm{~kJ} / \mathrm{mm}$, whereas $T p$ up to $300{ }^{\circ} \mathrm{C}$. In particular, ADI 1050 exhibits two heat-affected zones (Fig. 4): HAZ1 microstructural response is fully influenced by HI and Tp whereas HAZ2 undergoes light softening for any combination of $\mathrm{HI}$ and $\mathrm{Tp}$. Different behaviour of HAZ1 and HAZ2 is shown in Figs. 5 and 6 ; during the preliminary tests, it has been found that the microstructure remains the same for $\mathrm{HI}$ and $\mathrm{Tp}$ above 1.8 $\mathrm{kJ} / \mathrm{mm}$ and $250{ }^{\circ} \mathrm{C}$, respectively.

Due to the isothermal heat treatment at $350{ }^{\circ} \mathrm{C}$ required for $\mathrm{ADI} 1050$, proper $\mathrm{HI}$ and $\mathrm{Tp}$ were selected in order to avoid martensite formation within HAZ1; thus, requirement was to obtain $\mathrm{HBW}$ values similar to the base material, and secondly to avoid extended softening. 
Table 4 Brinell hardness measurement HBW 187.5-2.5 according to UNI EN ISO 6506-1:2015

\begin{tabular}{|c|c|c|c|c|c|c|c|c|c|c|c|c|c|c|c|}
\hline \multirow[t]{2}{*}{ Specimen } & \multicolumn{3}{|c|}{$\begin{array}{l}\text { ADI } 1050 \\
\text { Base material }\end{array}$} & \multicolumn{3}{|c|}{$\begin{array}{l}\text { HAZ } \\
\text { ADI } 1050\end{array}$} & \multicolumn{3}{|c|}{ Weld metal } & \multicolumn{3}{|c|}{$\begin{array}{l}\text { HAZ } \\
\text { S355J2 }\end{array}$} & \multicolumn{3}{|c|}{$\begin{array}{l}\text { S355J2 } \\
\text { base material }\end{array}$} \\
\hline & 1 & 2 & 3 & 4 & 5 & 6 & 7 & 8 & 9 & 10 & 11 & 12 & 13 & 14 & 15 \\
\hline A & 364 & 364 & 363 & 385 & 301 & 312 & 224 & 209 & 202 & 212 & 195 & 185 & 161 & 163 & 163 \\
\hline B1 & 363 & 362 & 362 & 415 & 298 & 298 & 202 & 189 & 190 & 198 & 186 & 185 & 161 & 163 & 163 \\
\hline $\mathrm{C}$ & 353 & 331 & 363 & 363 & 321 & 354 & 204 & 187 & 187 & 224 & 195 & 185 & 161 & 165 & 163 \\
\hline
\end{tabular}

It is worth noting that remelted metal microstructure, because of metastable solidification after welding, consists in ledeburite at room temperature (Fig. 4): cooling rate after welding is always too fast to allow carbon in molten metal to precipitate in the form nodules once again. Therefore, carbon remains in the matrix as iron carbides which forms the ledeburite.

The next step required $\mathrm{HI}$ and $\mathrm{Tp}$ to be adjusted for creating BoP with filler material in order to evaluate different modes of metal transfer and the tendency to crack formation. Fully mechanised GMAW welding process with $\mathrm{S} C \mathrm{NiFe}-2 \mathrm{EN}$ ISO $1071 ø 1.2-\mathrm{mm}$ filler material and MCAW-welding process with $\mathrm{T}$ C NiFe T3-CI EN ISO $1071 ø 1.2-\mathrm{mm}$ filler material (by Voestalpine Bohler Welding) have been adopted; $\mathrm{Ar}-\mathrm{CO}_{2}$ 80-20 ISO14175 M21 gas shielding was used.

Based on the evidence coming from macrographic test (UNI EN ISO 17639), visual testing (VT) (UNI EN ISO 17637), penetrating testing (PT) (UNI EN ISO 3452-1), Brinell Hardness (HBW) test (UNI EN ISO 6506-1) and micrographic test (EN ISO 945-1), pulsed arc and short arc GMAW welding processes gave the best results. The relevant welding process parameters are reported in Table 1.

\subsection{Specimen preparation}

Taking into consideration the actual specimens' dimensions, the misalignments and the different geometries of the dissimilar welded joints investigated (see Fig. 2), the parameters were tuned as shown in Table 1.

Regarding the microstructure within HAZ at the ADI side, the prevention of martensite formation and crack nucleation was the major challenge. Therefore, as discussed in Section 3.1, the welding parameters were identified to obtain a resulting hardness as close as possible to the base ADI material. On the other hand, it was not possible to avoid the formation of ledeburite at the weld metal interface: after re-melting, ductile iron is always subjected to metastable solidification in this zone. Table 2 reports the proper set of parameters for pulsed-arc fully mechanised GMAW welding, employed to join specimens.

The specimens' geometry and preparation are summarised in Table 3. All specimens were monitored by macrographic/ micrographic analyses and subjected to VT, PT and HBW tests. Quality level for imperfections was according to ISO 5817-B.
Fig. 7 HV1 measurement on cross-section of a welded joint type B2 (full-penetration butt welded joints, flush ground)

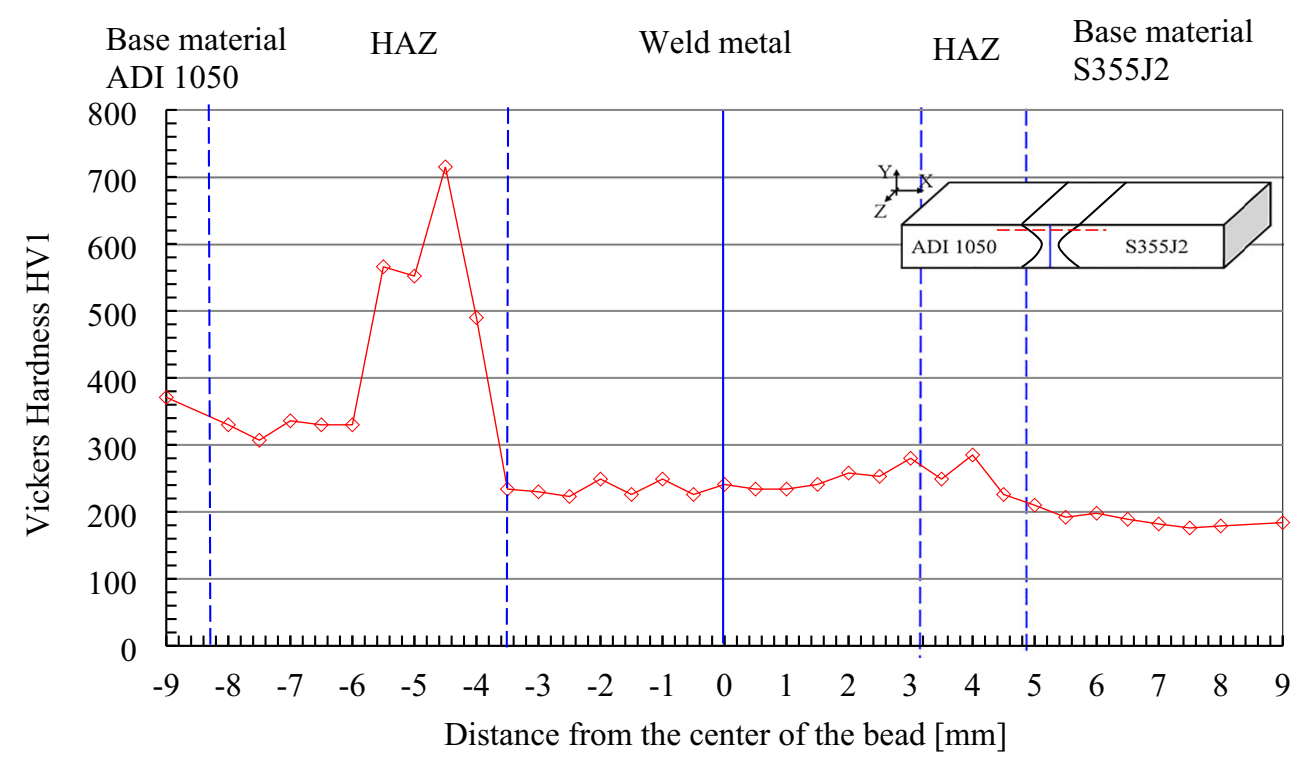



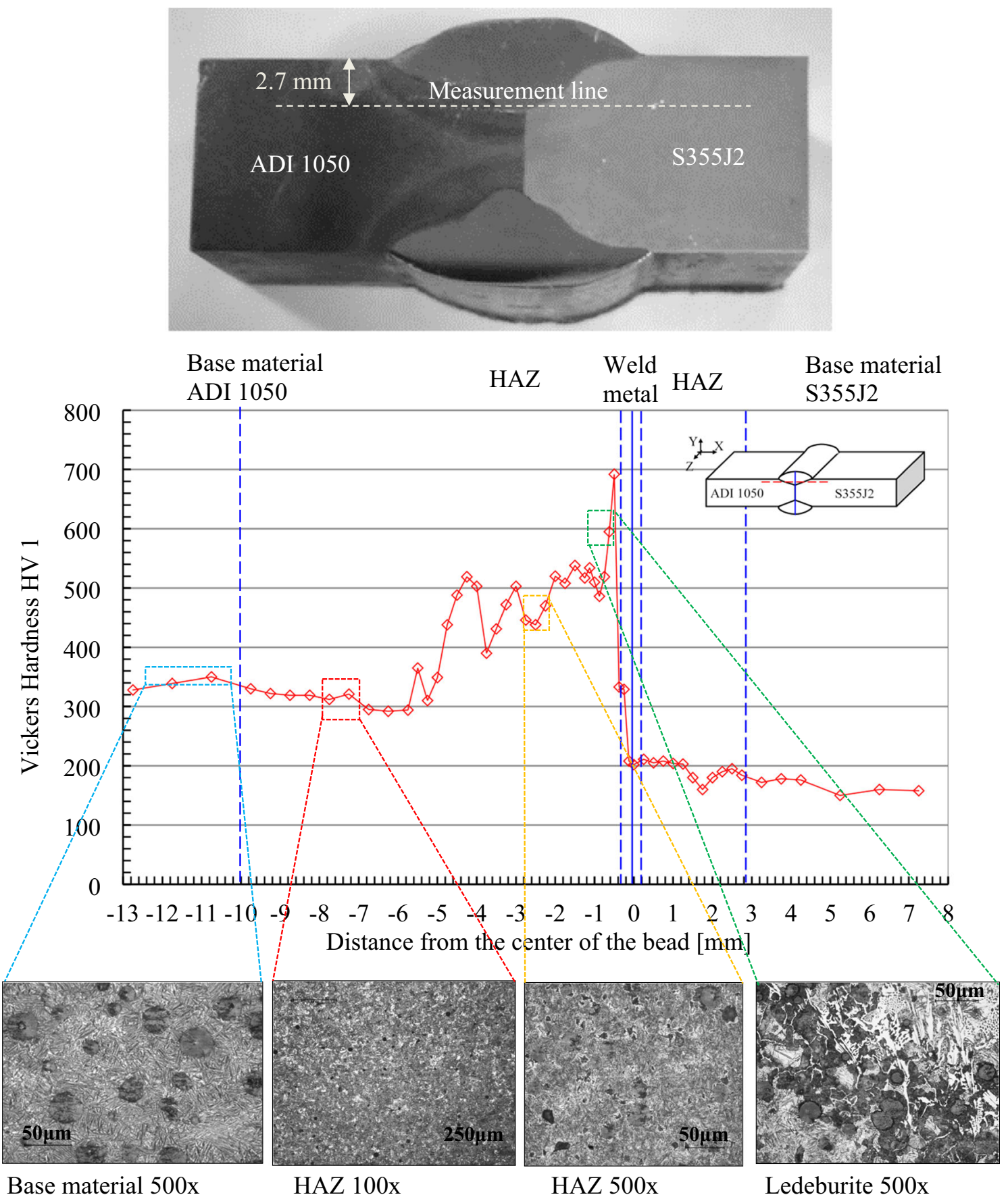

Fig. 8 HV1 measurement on cross-section of a welded joint type A (partial-penetration butt welded joint)

\section{Specimens' characterisation}

\subsection{Hardness measurements}

Brinell hardness HBW measurements have been performed on all specimens and results are reported in Table 4. The results confirm that heat-affected zone of ADI 1050 mainly consists in graphite nodules in pearlitic matrix and ledeburite layer close to weld metal; HAZ of S355J2 consists in ferritic-pearlitic matrix.
However, Brinell hardness test producing a wide indentation area on material surface, the measurement result is an average value over several microstructural phases; for this reason, it is not suitable to identify very narrow phase transitions.

After that, also Vickers hardness HV1 profiles have been measured in order to recognise microstructural alterations. The results are reported in Figs. 7, 8, 9 and 10. Figures. 8, 9 and 10 show how phase transitions can be recognised better using HV1 measurement. 

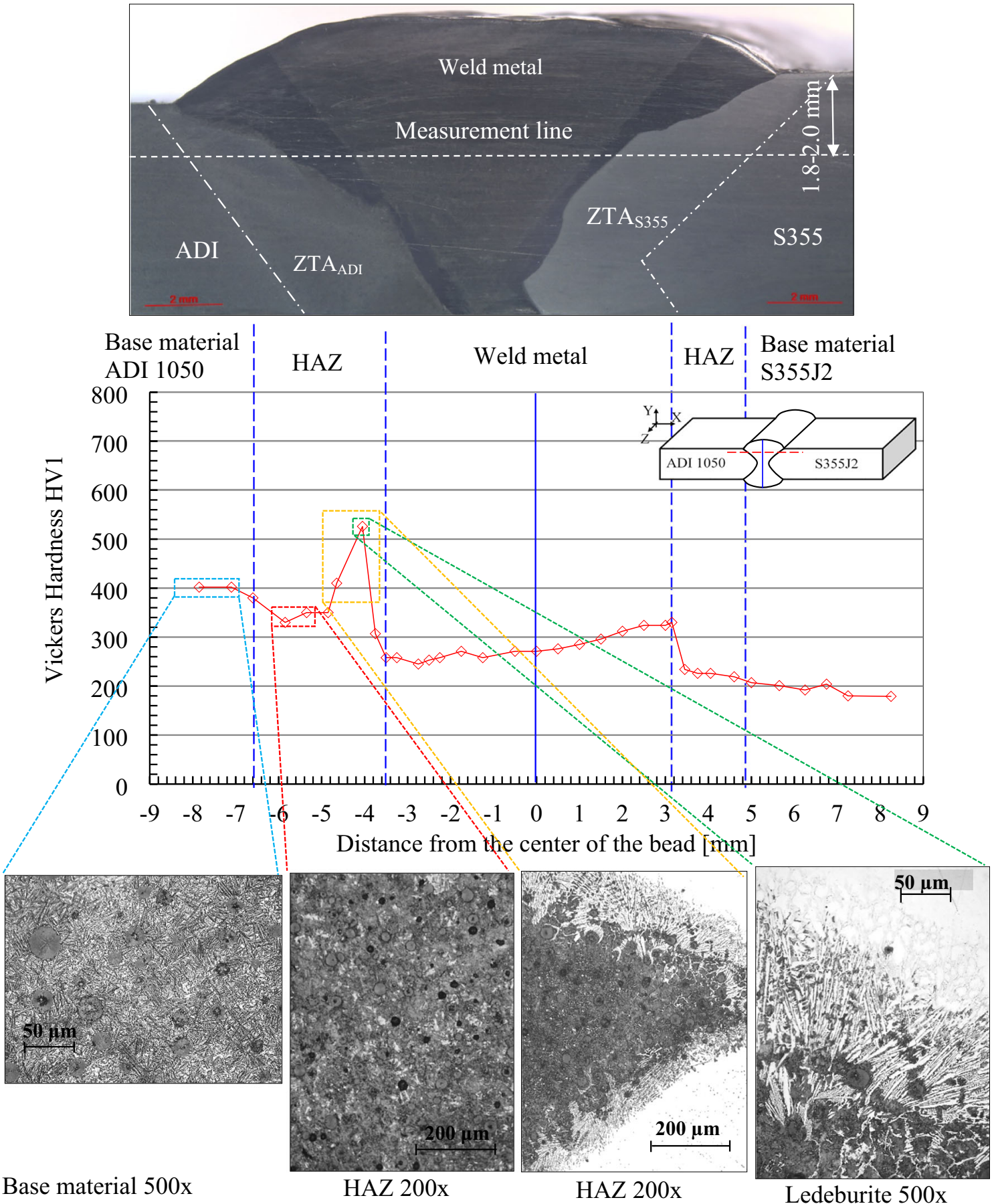

Fig. 9 HV1 measurement on cross-section of a welded joint type B1 (full-penetration butt welded joint)

\subsection{Residual stress measurements}

Residual stresses were measured by the X-ray diffraction method on a selection of specimens, namely a partialpenetration and a full-penetration butt welded joints. Residual stresses were measured at the weld bead welded last, according to the welding pass order sketched in Table 3 .
Figure 11 reports the measurement paths originating from the weld toe at the ADI and steel sides, respectively, along which the residual stresses $\sigma_{\mathrm{xx}}$ and $\sigma_{\mathrm{zz}}$ were measured, while Table 5 reports details on the experimental parameters of the adopted X-ray device, i.e. GNR SpiderX. The measured residual stresses $\sigma_{\mathrm{xx}}$ and $\sigma_{\mathrm{zz}}$ are reported in Fig. 12 as a function of the distance from the weld toe. 

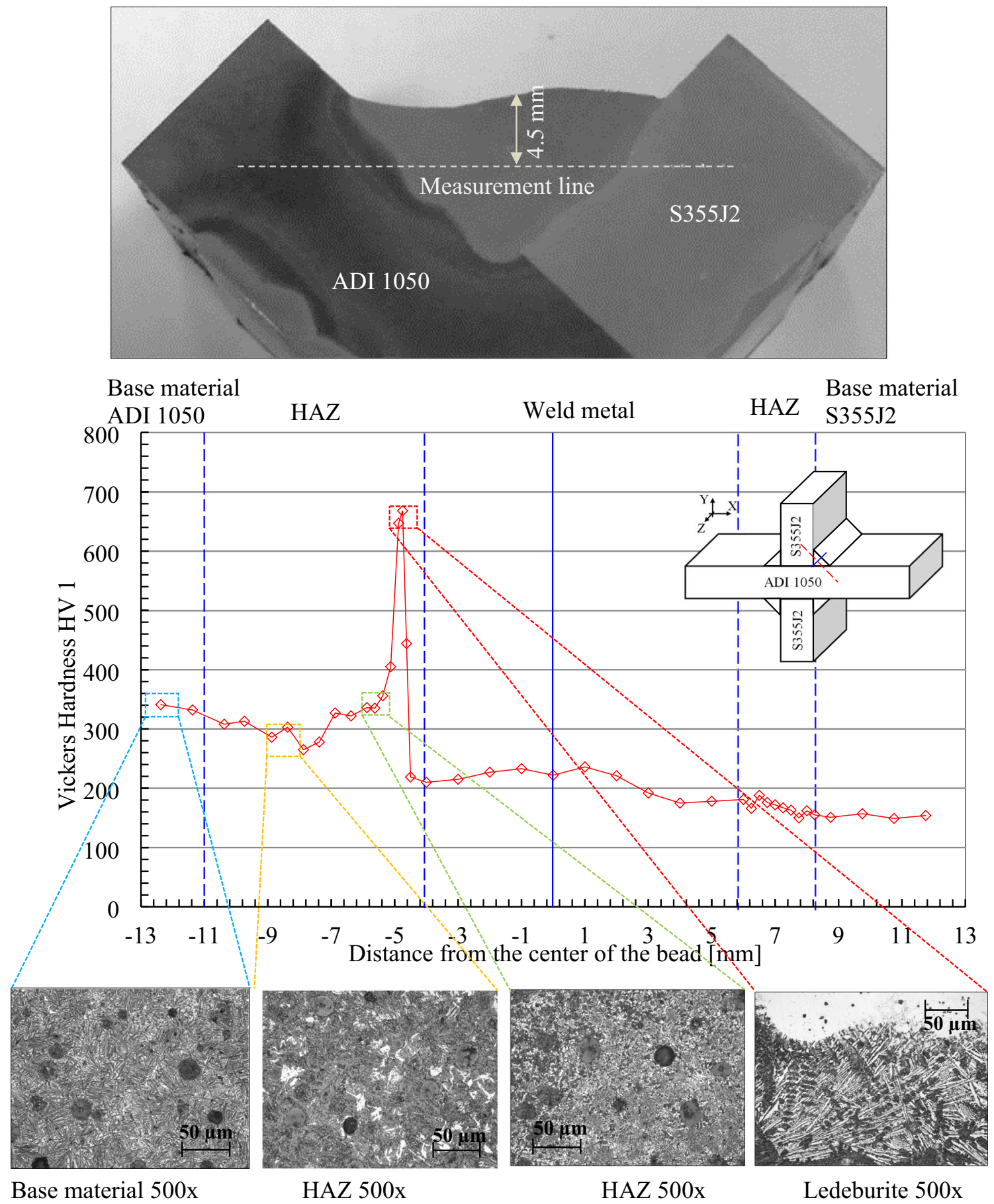

Fig. $10 \mathrm{HV} 1$ measurement on cross-section of a welded joint type $\mathrm{C}$ (nlc fillet-welded transverse stiffener joint)

Figure 12 shows that both the analysed specimens have high compressive residual stresses close to the weld toe, while far from the weld toe residual stresses become tensile in the case of partial-penetration butt welded joint and almost zero in the case of full-penetration butt welded joint. Moreover, it can be observed that the obtained residual stress values are more compressive at the steel side than at the ADI side (see Figs. 12(b, d) and (a, c) in comparison).

\subsection{Misalignments}

Linear (e in Fig. 13) and angular ( $\alpha$ in Fig. 13) misalignments were measured in as-welded specimens, namely partialpenetration and full-penetration butt welded joints and nlc fillet-welded transverse stiffener joints. Misalignments were measured by clamping one side of each welded joint and by measuring the $\mathrm{Y}$-coordinate of four points $\left(\mathrm{O}, \mathrm{A}, \mathrm{A}^{\prime}, \mathrm{O}^{\prime}\right)$ with a centesimal digital dial indicator. After zeroing the indicator 


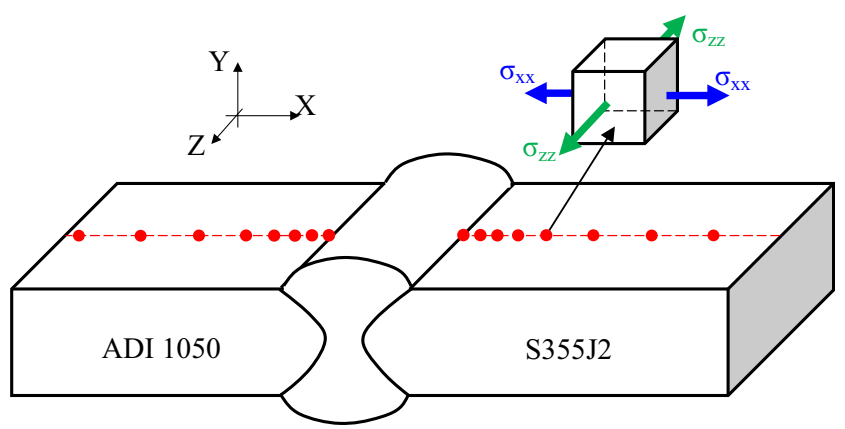

Fig. 11 Residual stress components and paths for residual stress measurement

Table 5 Residual stress measurement by the X-ray diffraction method: adopted device and experimental parameters

\begin{tabular}{ll}
\hline Surface preparation & Removal of oxide layer using $\mathrm{HCl}$ \\
X-ray device & GNR Spider X \\
Radiation & Cr-K $\alpha$ with vanadium filter, \\
& penetration depth $15 \mu \mathrm{m}$ \\
Collimator size & $1 \mathrm{~mm}$ \\
Method & $\sin ^{2} \psi$ method \\
Measurement paths & see Fig. 11 \\
Residual stress components & $\sigma_{\mathrm{xx}}$ and $\sigma_{\mathrm{zz}}$ (see Fig. 11) \\
Acquisition time & $500 \mathrm{~s} / \psi$ angle \\
$\psi-$-angles & $7 \psi$-angles $-35^{\circ}<\psi<35^{\circ}$ \\
Elastic constants & $E=210 \mathrm{GPa}, \nu=0.3$
\end{tabular}
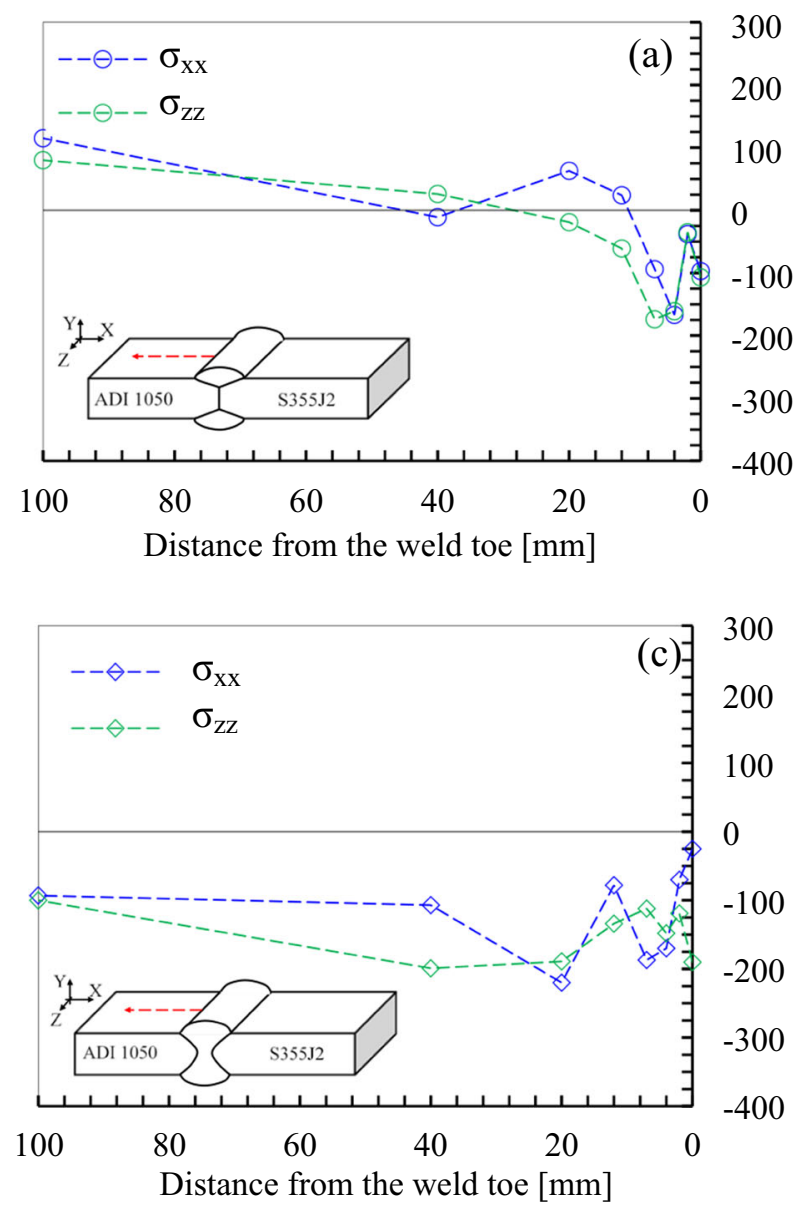

300
200
100
0
-100
-200
-300
-400

Fig. 12 Residual stresses along the path shown in Fig. 11 by the X-ray diffraction method in (a) and (b) partial-penetration butt welded joint and in (c) and (d) full-penetration butt welded joint. Dashed lines have been at the reference point (point $\mathrm{O}, \mathrm{Y}=0$ ) near the clamped extremity of the joint, the $\mathrm{Y}$-coordinate was measured at the other points: $A$ and $A^{\prime}$, which were located near one of the weld toes (see Fig. 13), and $\mathrm{O}^{\prime}$, located at the opposite extremity. Doing so, the axis of each plate was determined and then the linear (e in Fig. 13) and angular ( $\alpha$ in Fig. 13) misalignments were evaluated.

The results are reported in Table 6 . It can be observed that all measured specimens are characterised by rather high values of both linear (e in Fig. 13) and angular ( $\alpha$ in Fig. 13) misalignments, translating into a total linear misalignment between the two ends of each specimen $(\Delta \mathrm{Y}$ in Fig. 13) in the range from 0.35 to $4 \mathrm{~mm}$.

\section{Fatigue tests}

\subsection{Testing parameters}

Experimental fatigue tests have been performed on welded joints presented in Fig. 2. The tested welded joint geometries are reported in Fig. 14 along with details about the loading
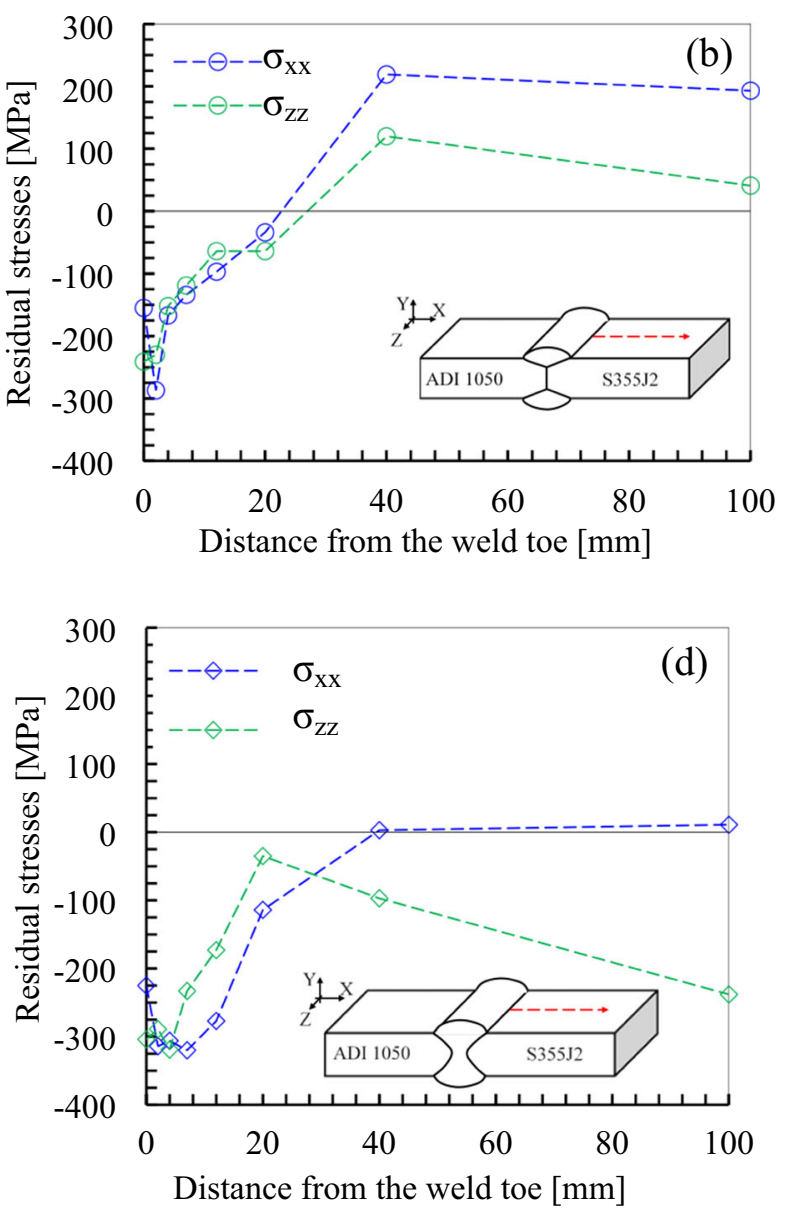

added between measured values only to increase readability; however, they do not represent the actual trend of residual stresses 
Fig. 13 Definition of linear (e), angular $(\alpha)$ and total $(\Delta \mathrm{Y})$ misalignments

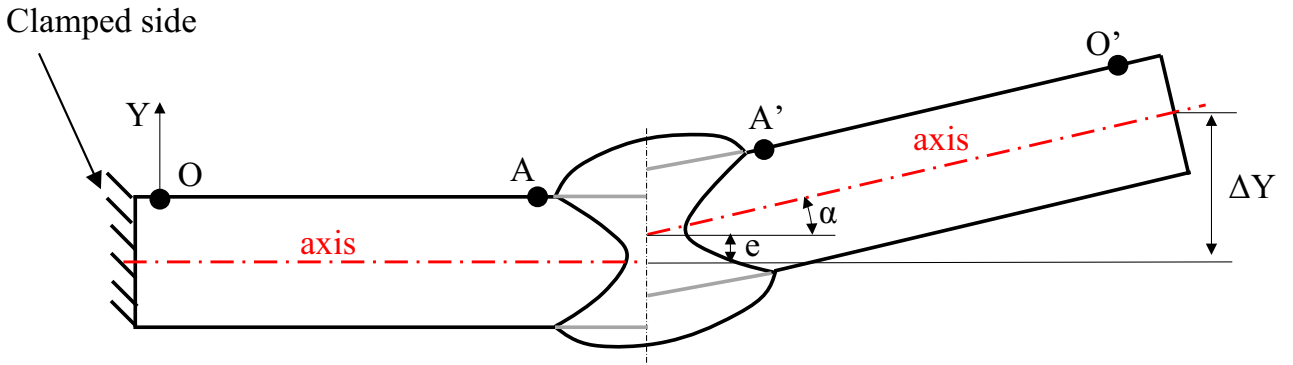

conditions, while Table 7 summarises the testing conditions. Given the measured misalignments previously reported in Table 6, the fatigue loads were applied to each test series as follows:

Table 6 Linear (e), angular $(\alpha)$ and total $(\Delta \mathrm{Y})$ misalignments measured in as-welded joints.

\begin{tabular}{llll}
\hline Specimen code & $\mathrm{e}[\mathrm{mm}]$ & $\alpha\left[^{\circ}\right]$ & $\Delta \mathrm{Y}[\mathrm{mm}]$ \\
\hline A_1_5 & 0.52 & 1.00 & 2.71 \\
A_1_6 & 0.59 & 0.60 & 1.90 \\
A_2_1 & 0.03 & 0.60 & 1.41 \\
A_2_3 & 0.07 & 0.64 & 1.54 \\
A_2_4 & 0.06 & 0.46 & 1.07 \\
A_2_2 & 0.17 & 0.69 & 1.77 \\
A_11_1 & 0.29 & 0.75 & 1.24 \\
A_11_2 & 0.28 & 0.77 & 1.15 \\
A_11_3 & 0.36 & 0.93 & 1.32 \\
A_11_5 & 0.20 & 0.60 & 0.89 \\
A_11_4 & 0.20 & 0.75 & 1.27 \\
A_3_4 & 0.21 & 0.51 & 1.33 \\
B1_2_4 & 0.76 & -0.50 & 0.34 \\
B1_2_3 & 0.81 & -0.46 & 0.37 \\
B1_2_6 & 0.60 & -0.35 & 0.38 \\
B1_6_1 & 0.16 & 0.51 & 0.85 \\
B1_6_2 & 0.21 & 0.60 & 0.99 \\
B1_6_3 & 0.09 & 0.70 & 1.53 \\
C_6_3 & 0.66 & 1.46 & 3.51 \\
C_7_1 & 0.20 & 0.35 & 0.85 \\
C_8_3 & 0.66 & 1.46 & 3.51 \\
C_7_3 & 0.20 & 0.59 & 1.30 \\
C_5_1 & 0.58 & 1.30 & 3.12 \\
C_8_1 & 0.64 & 1.53 & 3.57 \\
C_5_2 & 0.20 & 0.36 & 0.86 \\
C_15_2 & 0.58 & 1.43 & 3.58 \\
C_17_4 & 0.40 & 1.46 & 3.52 \\
C_16_3 & 0.53 & 1.54 & 1.55 \\
C_17_1 & 0.59 & 1.40 & \\
C_13_3 & 0.76 & & \\
C_16_2 & & & \\
\hline
\end{tabular}

- partial-penetration butt welded joints (Fig. 14a) were fatigue tested under axial loading to assess weld root as well as weld toe failure, after having milled the clamping surfaces as shown in Fig. 15 to minimise the misalignments and reduce secondary bending effects;

- full-penetration butt welded joints (Fig. 14b) were tested under four-point bending loading, in order to avoid secondary bending effects;

- full-penetration butt welded joints, flush ground (Fig. 14c), were fatigue tested under axial loading because misalignments had been removed previously by milling the specimen surfaces to remove the weld caps;

- nlc fillet-welded transverse stiffener joints (Fig. 14d) were fatigue tested under four-point bending loading, in order to avoid secondary bending effects.

All structural details were tested in standard laboratory environment, using an MFL axial servo-hydraulic machine (see Fig. 16), which has a maximum load capacity of $250 \mathrm{kN}$ and it is equipped with an MTS TestStar IIm digital controller. The experimental tests were carried out under closed-loop load control by applying sinusoidal cyclic load with constant amplitude and nominal load ratio $R$ as reported in Table 7. The load frequency was set ranging from 10 up to $30 \mathrm{~Hz}$ depending on the applied load level. The number of loading cycles $N_{f}$ at complete separation has been defined as the fatigue life to failure of each specimen, while run-out was fixed at $2 \cdot 10^{6}$ cycles, when no failure occurred.

\subsection{Damage analysis}

Figures 17, 18, 19 and 20 show some examples of fracture surfaces, obtained after fatigue testing each series.

Partial-penetration butt welded joints show multiple crack initiation locations, as reported in Fig. 17. In most cases, crack initiated at the root side, then propagated through the weld throat. Propagating cracks were observed also at the interface between the ADI plate and 

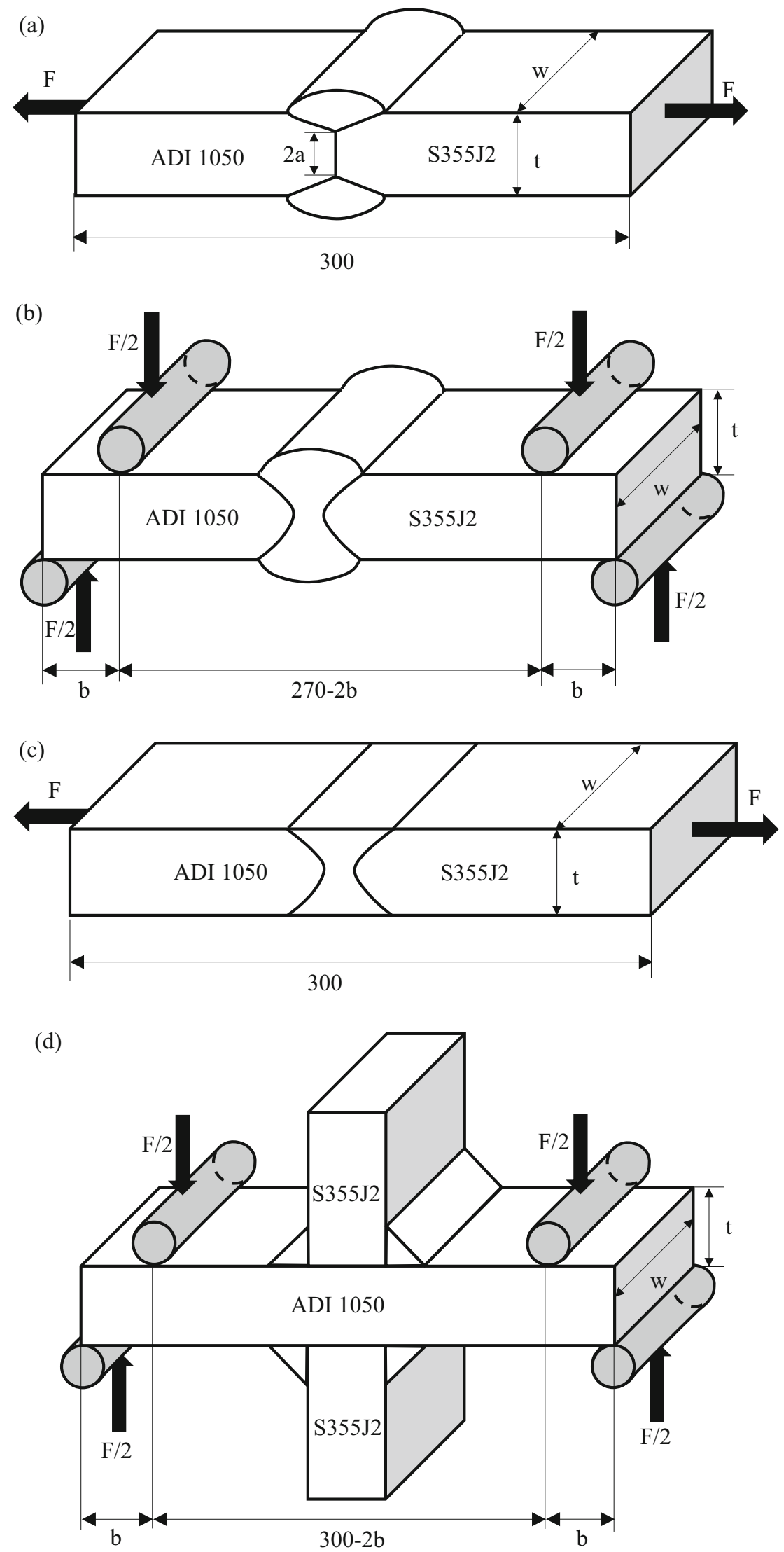

Fig. 14 a-d Geometries and loading conditions of dissimilar welded joints tested under fatigue loading 
Table 7 Testing conditions of the welded joints

\begin{tabular}{|c|c|c|c|c|c|c|}
\hline Test series & Welded joint geometry & $\begin{array}{l}\text { Testing } \\
\text { condition* }\end{array}$ & $\begin{array}{l}\text { Tested } \\
\text { specimens }\end{array}$ & Load $^{\#}$ & $\begin{array}{l}\text { Nominal load ratio } \\
R\end{array}$ & Failure criterion \\
\hline $\begin{array}{l}\text { A } \\
\text { B1 }\end{array}$ & $\begin{array}{l}\text { Partial-penetration butt welded joints } \\
\text { Full-penetration butt welded joints }\end{array}$ & \multirow[t]{3}{*}{ AW } & $\begin{array}{l}12 \\
14\end{array}$ & $\begin{array}{l}\mathrm{Ax} \\
4 \mathrm{~PB}\end{array}$ & $\begin{array}{l}0.05 \\
0.05\end{array}$ & \multirow[t]{3}{*}{$\begin{array}{l}\text { Complete } \\
\text { separation }\end{array}$} \\
\hline B2 & Full-penetration butt welded joints, flush ground & & 6 & Ax & 0.05 & \\
\hline $\mathrm{C}$ & nlc fillet-welded transverse stiffener joints & & $\begin{array}{l}17 \\
9\end{array}$ & $4 \mathrm{~PB}$ & $\begin{array}{l}0.05 \\
0.5\end{array}$ & \\
\hline
\end{tabular}

*AW $=$ as welded

${ }^{\#} \mathrm{Ax}=$ axial load, $4 \mathrm{~PB}=$ four-point bending load

the weld bead and, in a few cases, at the weld toe at the ADI side, too.

Dealing with full-penetration butt welded joints, Fig. 18 shows that the fatigue crack initiation always occurred at the weld toe at the ADI side, then the crack propagated through the thickness of the welded joint. Only in one specimen, the fatigue crack initiation was observed at the weld toe at the steel side, as reported in Table 9.

Concerning full-penetration butt welded joints, flush ground, crack initiation always occurred in the ledeburite region (highlighted in previous Figs. 7, 8). Then, cracks propagated mainly at the interface between the ADI plate and the weld bead (see Fig. 19) and, in some cases, across the thickness of the welded joint.

In the case of nlc fillet-welded transverse stiffener joints, the fatigue crack initiation could just occur at the weld toe at the ADI side. After initiation, crack propagated through the thickness of the welded joint as shown in Fig. 20.

\subsection{Fatigue results}

The detailed experimental results are reported in Tables 8 , 9, 10, 11 and 12, where the applied load, the obtained fatigue life and the crack initiation location are listed for each tested welded joint. In the case of partial-penetration butt welded joints under axial loading, the nominal stress range $\Delta \sigma$ (defined as the difference between the maximum and the minimum value) has been calculated with respect to the weld throat area according to the following expression (see also Fig. 14a):

$\Delta \sigma=\frac{\Delta F}{\mathrm{~A}_{\text {throat }}}=\frac{\Delta F}{W(t-2 a)}$

In the case of full-penetration butt welded joints and nlc fillet-welded transverse stiffener joints under four-point bending loading, the expression (2) yields the nominal stress range (Figs. 14b and d):

$\Delta \sigma=\frac{\Delta M_{\mathrm{f}}}{W_{\mathrm{f}}}=\frac{\frac{\Delta F}{2} b}{\frac{1}{6} W t^{2}}$

Dealing with full-penetration butt welded joints, flush ground, under axial loading, the nominal stress range has been evaluated in the gross section area according to the following expression (see also Fig. 14c):

Fig. 15 Partial-penetration butt welded joints: clamping surfaces milled to minimise the misalignments

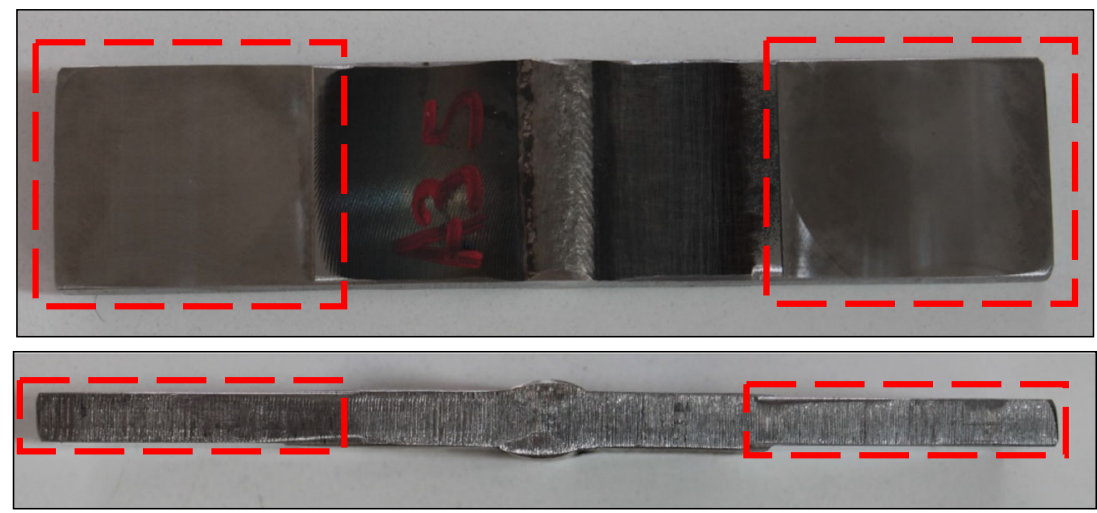


Fig. 16 a, c A partial-penetration butt welded joint and a fullpenetration butt welded joint, flush ground, tested in the axial fatigue test machine under axial loading. b, d A full-penetration butt welded joint and a nlc filletwelded transverse stiffener joints tested in the fatigue test machine under four-point bending loading by means of a dedicated loading fixture
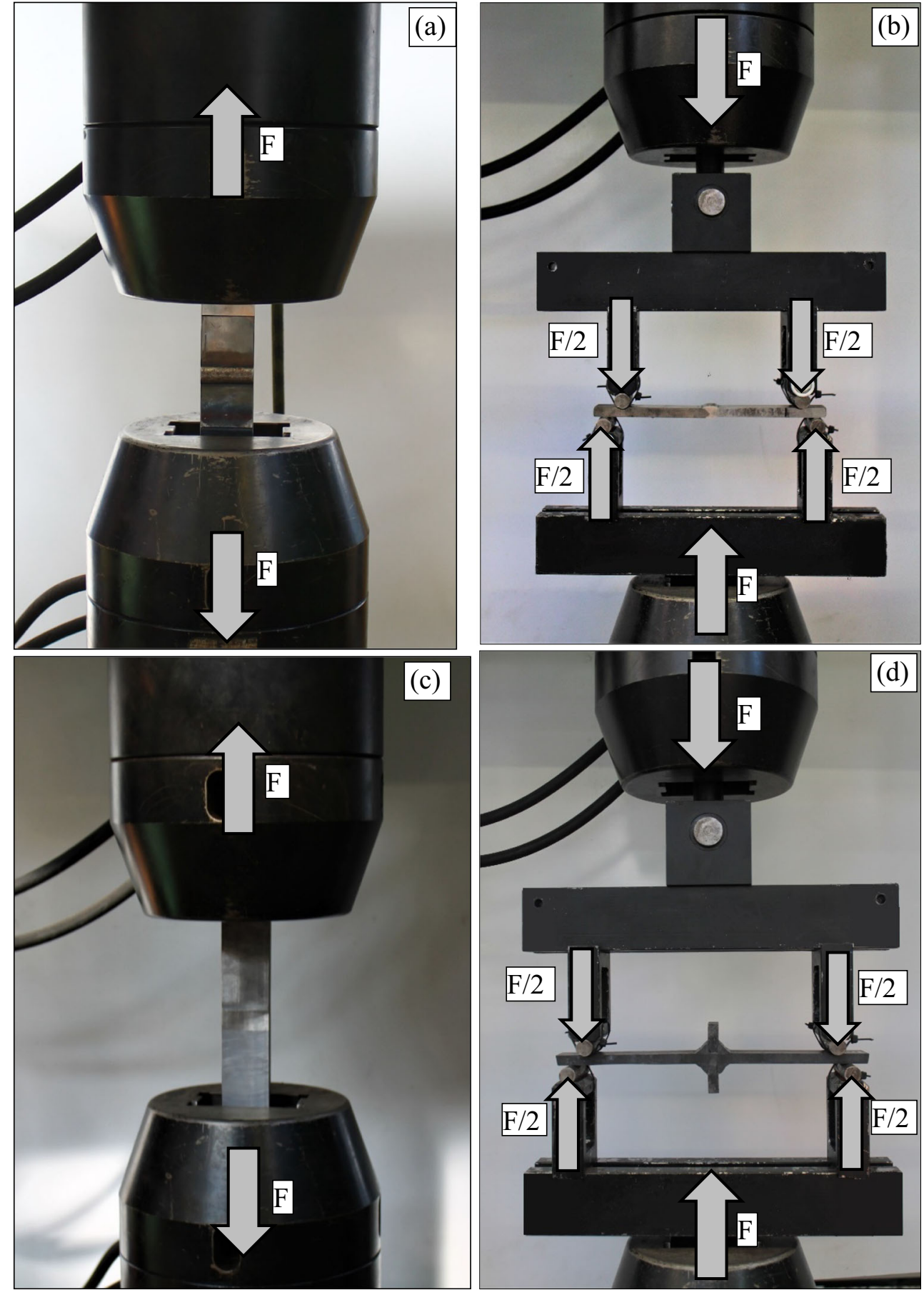

$\Delta \sigma=\frac{\Delta F}{A_{g}}=\frac{\Delta F}{W t}$

Figures 21, 22, 23 and 24 show the fatigue results in terms of the applied nominal stress range $\Delta \sigma$ versus the number of cycles to failure. The scatter bands refer to survival probabilities of 2.3 and $97.7 \%$ and to a $95 \%$ confidence level. For comparison purposes, the fatigue curves fitted on experimental fatigue results by imposing an inverse slope $k=3$ and with reference to a survival probability of $97.7 \%$ have been included in the figures. Table 13 summarises the endurable stress ranges at 2 million loading cycles for a survival probability of $97.7 \%$, the inverse slope $k$, and the scatter index $T_{\sigma}$ for each test series. 
Fig. 17 Fracture surfaces of partial-penetration butt welded joints tested under axial fatigue loading

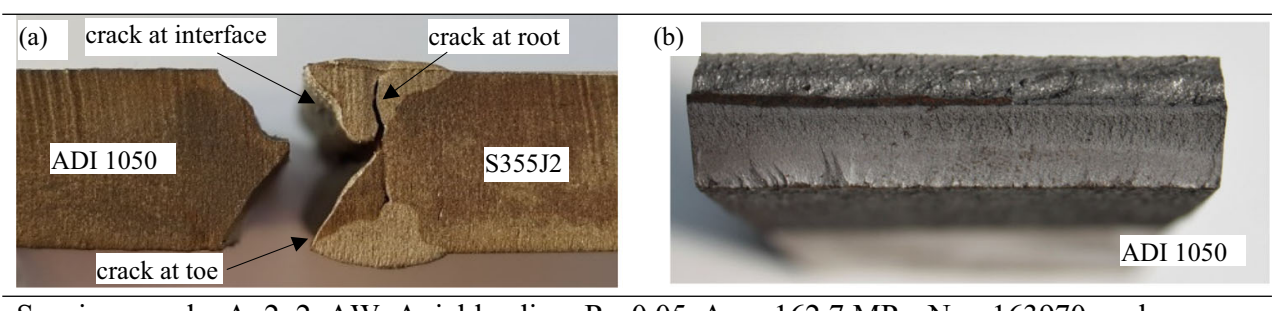

Specimen code: A_2_2, AW, Axial loading, $\mathrm{R}=0.05, \Delta \sigma=162.7 \mathrm{MPa}, \mathrm{N}_{\mathrm{f}}=163970$ cycles

(c)
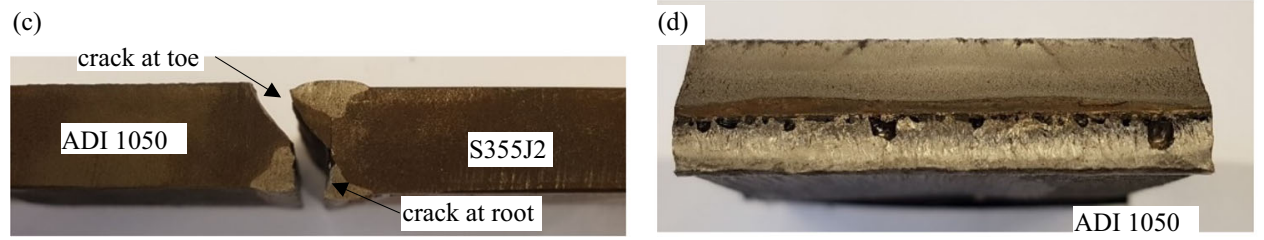

Specimen code: A_2_4, AW, Axial loading, $\mathrm{R}=0.05, \Delta \sigma=142.3 \mathrm{MPa}, \mathrm{N}_{\mathrm{f}}=275454$ cycles

(e)
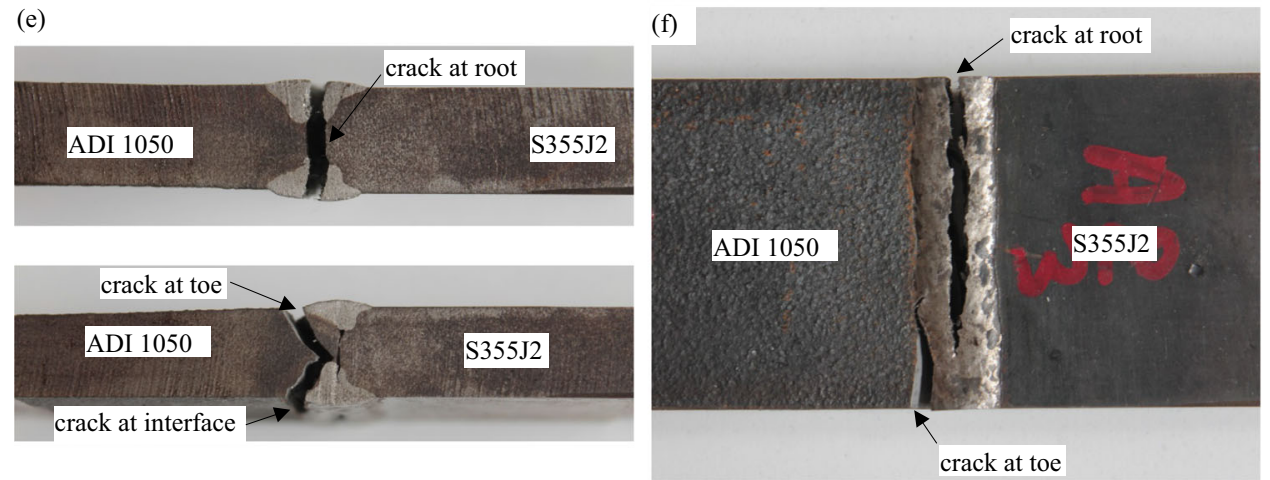

Specimen code: A $2 \_3$, AW, Axial loading, $\mathrm{R}=0.05, \Delta \sigma=105.6 \mathrm{MPa}, \mathrm{N}_{\mathrm{f}}=1926134$ cycles
It can be observed from Figs. 21, 22, 23 and 24 that, referring to a survival probability of $97.7 \%$ and 2 million loading cycles, the tested details exhibit an endurable stress range higher than the FAT values suggested by Eurocode 3 and IIW Recommendations [22, 24] for the corresponding homogeneous steel welded joints. It is worth noting that according to IIW Recommendations $[22,24]$, the FAT values should be modified to account for the load ratio $R$. More in detail, when dealing with load ratio $R=0.05$ the FAT values should be enhanced by a factor $f(R)$, equal to 1 in the case of 'small-scale thinwalled simple structural elements containing short welds - medium residual stress case' as assumed for the FAT values reported in Figs. 21, 22, 23 and 24, while it would be equal to 1.18 in the case of 'wrought products with negligible residual stresses $(<0.2 \cdot \mathrm{fy})$ or stress
Fig. 18 Fracture surfaces of fullpenetration butt welded joints tested under four-point-bending fatigue loading
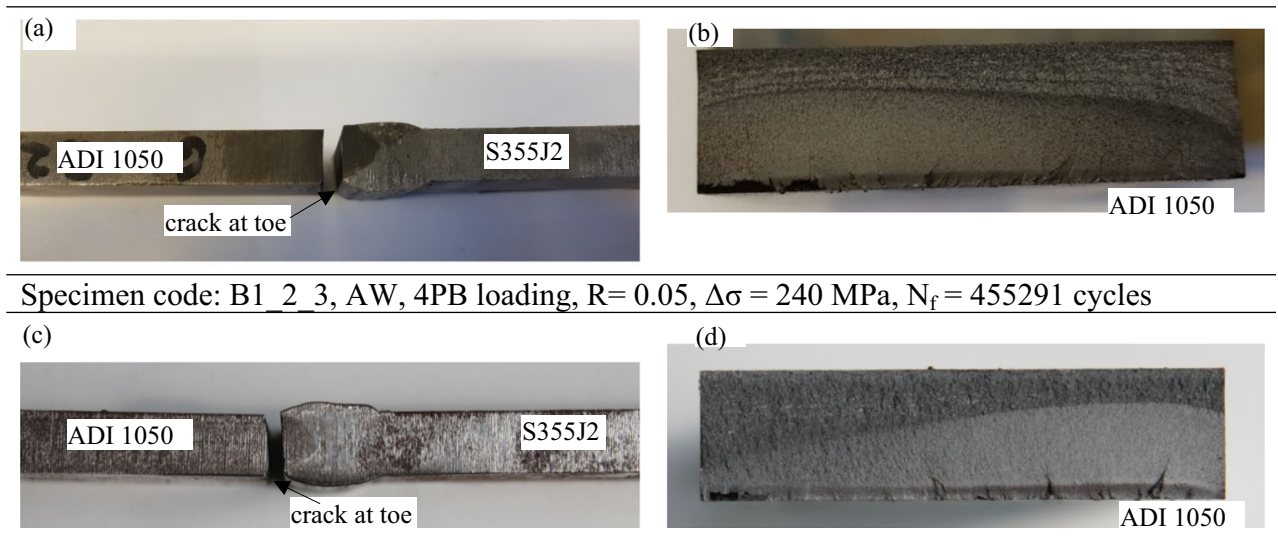

Specimen code: $\mathrm{B} 1 \_5$ 3, AW, 4PB loading, $\mathrm{R}=0.05, \Delta \sigma=261 \mathrm{MPa}, \mathrm{N}_{\mathrm{f}}=974888$ cycles 
Fig. 19 Fracture surfaces of fullpenetration butt welded joints, flush ground, tested under axial fatigue loading (a)

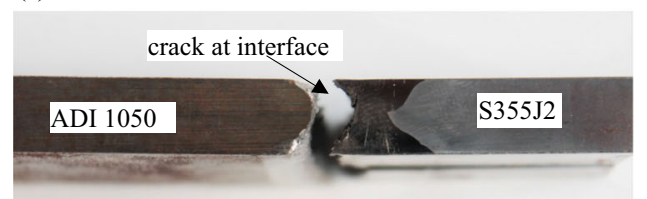

(b)

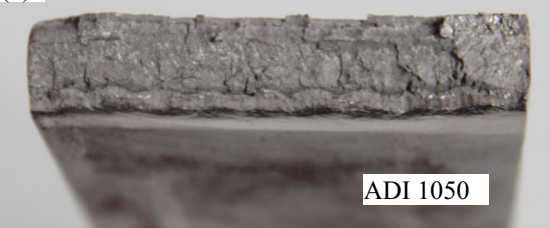

Specimen code: B2_4_2, AW, Axial loading, $\mathrm{R}=0.05, \Delta \sigma=320 \mathrm{MPa}, \mathrm{N}_{\mathrm{f}}=109630$ cycles (c)
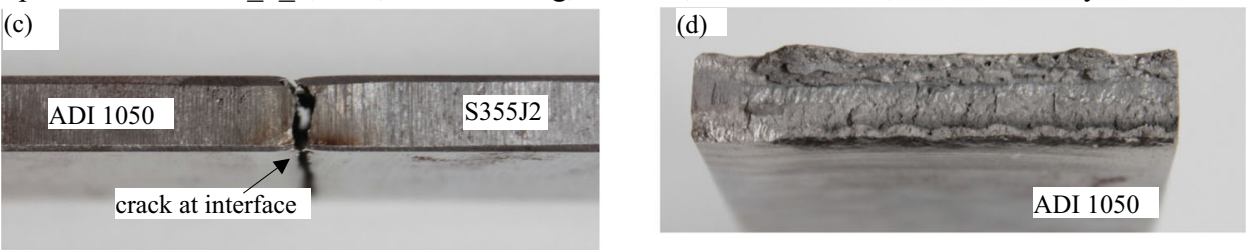

Specimen code: B2 8 5, AW, Axial loading, $\mathrm{R}=0.05, \Delta \sigma=299 \mathrm{MPa}, \mathrm{N}_{\mathrm{f}}=1764636$ cycles

relieved welded components-low residual stress case'. Moreover, it should be noted that only fatigue test results under axial loadings are comparable with the IIW recommendations.

\section{Conclusions}

In the present investigation, experimental fatigue tests have been carried out for the first time on austempered ductile
Fig. 20 Fracture surfaces of nlc fillet-welded transverse stiffener joints tested under four-pointbending fatigue loading

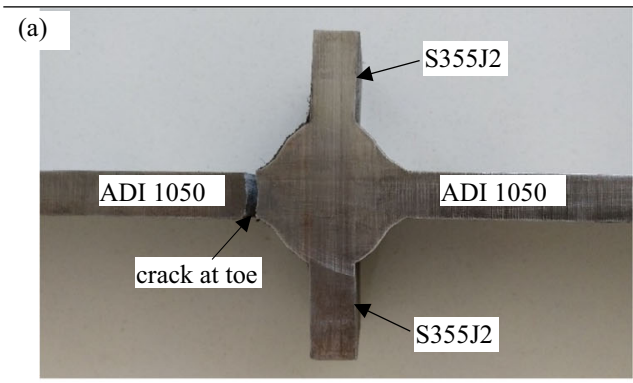

(b)

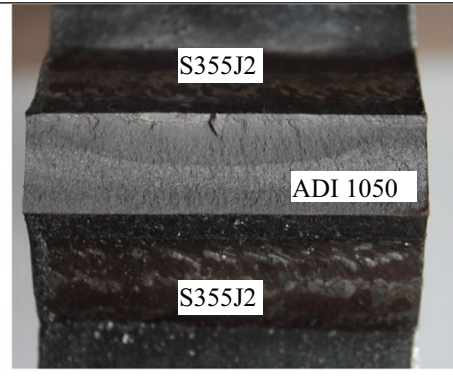

Specimen code: $\mathrm{C} 11$ 2, AW, 4PB loading, $\mathrm{R}=0.05, \Delta \sigma=465 \mathrm{MPa}, \mathrm{N}_{\mathrm{f}}=90293$ cycles (c)
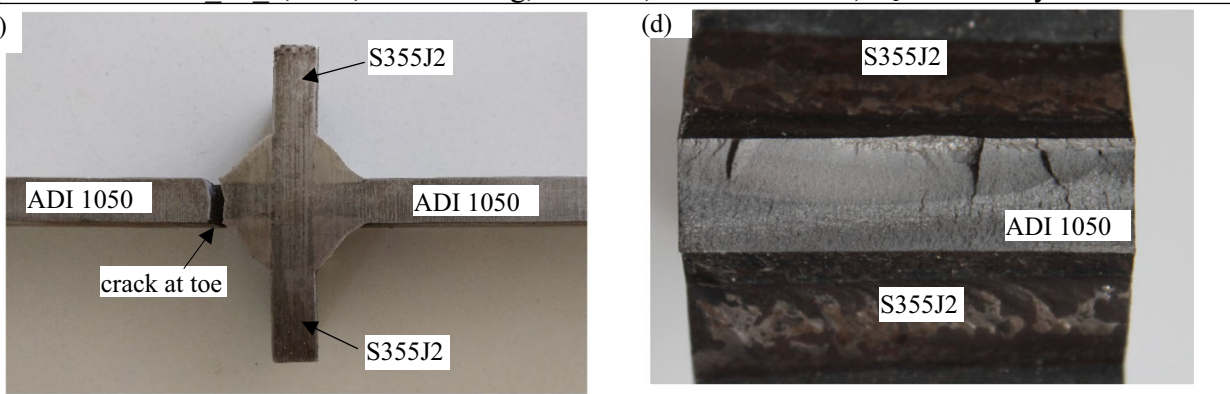

Specimen code: $\mathrm{C} \_11$ 1, AW, 4PB loading, $\mathrm{R}=0.05, \Delta \sigma=322 \mathrm{MPa}, \mathrm{N}_{\mathrm{f}}=782127$ cycles

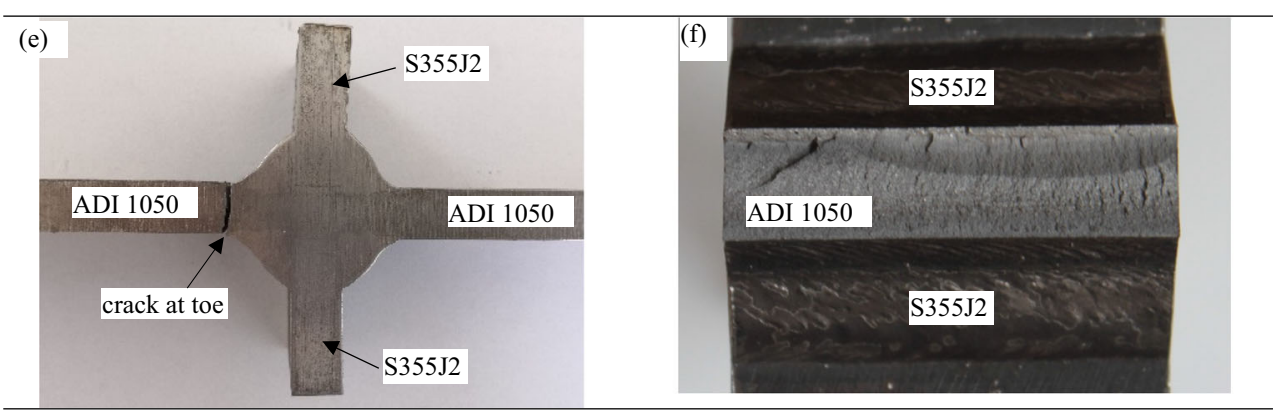

Specimen code: $\mathrm{C} \_92$ 2, AW, 4PB loading, $\mathrm{R}=0.5, \Delta \sigma=311 \mathrm{MPa}, \mathrm{N}_{\mathrm{f}}=212312$ cycles 
Table 8 Fatigue test results obtained from partial-penetration butt welded joints under pure axial loading with nominal load ratio $R=0.05$

\begin{tabular}{llllllllll}
\hline Specimen code & $W$ & $t$ & $2 \mathrm{a}$ & $A_{\text {throat }}$ & $R$ & $\Delta F$ & $\Delta \sigma^{\circ}$ & $N_{f}$ & Failure location* \\
\hline & {$[\mathrm{mm}]$} & {$[\mathrm{mm}]$} & {$[\mathrm{mm}]$} & {$\left[\mathrm{mm}^{2}\right]$} & & {$[\mathrm{kN}]$} & {$[\mathrm{MPa}]$} & {$[$ cycles] } \\
A_1_5 & 45.2 & 12.0 & 4.25 & 350.3 & 0.05 & 38.0 & 108.5 & 965951 & $\mathrm{R}+\mathrm{T}_{\mathrm{ADI}}$ \\
A_1_6 & 45.2 & 11.9 & 4.40 & 339.0 & 0.05 & 64.2 & 189.4 & 38752 & $\mathrm{~T}_{\mathrm{ADI}}+\mathrm{I}_{\mathrm{ADI}}$ \\
A_2_1 & 45.1 & 12.1 & 4.00 & 363.1 & 0.05 & 47.4 & 130.6 & 516620 & $\mathrm{R}+\mathrm{T}_{\mathrm{ADI}}+\mathrm{I}_{\mathrm{ADI}}$ \\
A_2_3 & 45.2 & 12.1 & 4.10 & 358.9 & 0.05 & 37.9 & 105.6 & 1926134 & $\mathrm{R}+\mathrm{T}_{\mathrm{ADI}}+\mathrm{I}_{\mathrm{ADI}}$ \\
A_2_4 & 45.1 & 12.1 & 3.95 & 365.3 & 0.05 & 52.0 & 142.3 & 275454 & $\mathrm{R}+\mathrm{T}_{\mathrm{ADI}}$ \\
A_2_2 & 45.4 & 11.9 & 4.00 & 358.3 & 0.05 & 58.3 & 162.7 & 163970 & $\mathrm{R}+\mathrm{T}_{\mathrm{ADI}}+\mathrm{I}_{\mathrm{ADI}}$ \\
A_11_1 & 40.2 & 10.1 & 3.90 & 246.9 & 0.05 & 40.3 & 163.2 & 340012 & $\mathrm{R}$ \\
A_11_2 & 40.4 & 10.1 & 3.65 & 260.6 & 0.05 & 35.0 & 134.3 & 666819 & $\mathrm{R}+\mathrm{I}_{\mathrm{ADI}}$ \\
A_11_3 & 40.5 & 10.1 & 3.80 & 255.2 & 0.05 & 45.0 & 176.4 & 228734 & $\mathrm{R}+\mathrm{I}_{\mathrm{ADI}}$ \\
A_11_5 & 40.4 & 10.1 & 3.15 & 280.4 & 0.05 & 31.5 & 112.3 & 894146 & $\mathrm{R}$ \\
A_11_4 & 40.3 & 10.1 & 3.90 & 249.9 & 0.05 & 31.0 & 124.1 & 867608 & $\mathrm{R}$ \\
A_3_4 & 40.0 & 10.0 & 4.00 & 240.0 & 0.05 & 65.5 & 270.8 & 67315 & $\mathrm{R}$ \\
\hline
\end{tabular}

${ }^{\circ} \Delta \sigma$ according to Eq. (1)

$* \mathrm{R}=$ root, $\mathrm{T}_{\mathrm{ADI}}=$ toe at the $\mathrm{ADI} 1050$ side, $\mathrm{I}_{\mathrm{ADI}}=$ interface between $\mathrm{ADI} 1050$ and weld bead

iron (EN-GJS-1050)-to-steel (S355J2) dissimilar arcwelded joints in the as-welded condition. The strength categories of some typical welded details have been derived to fill the gap in the technical literature and in all International Standards and Recommendations. After that, the strength categories have been compared with those provided by International Standards and Recommendations for homogeneous steel welded joints. It can therefore be concluded that:
- Partial-penetration butt welded joints have been fatigue tested under pure axial loading with $R=0.05$ and showed fatigue crack initiation mainly at the weld root side, while additional crack initiations and propagations have been observed at the weld toe and at the interface between plate and weld bead at the ADI side. They exhibited an endurable stress range of $67 \mathrm{MPa}$ (P.s. $97.7 \%$ and $N=2 \cdot 10^{6}$ cycles) to compare with FAT $36 \mathrm{MPa}$ of Eurocode 3 and

Table 9 Fatigue test results obtained from full-penetration butt welded joints under four-point-bending loading with nominal load ratio $R=0.05$

\begin{tabular}{lllllllllll}
\hline Specimen code & $W$ & $t$ & $W_{f}$ & $R$ & $\Delta F$ & $b$ & $\Delta M_{f}$ & $\Delta \sigma^{\circ}$ & $N_{f}$ & Failure location* \\
\hline & {$[\mathrm{mm}]$} & {$[\mathrm{mm}]$} & {$\left[\mathrm{mm}^{3}\right]$} & & {$[\mathrm{kN}]$} & {$[\mathrm{mm}]$} & {$[\mathrm{Nmm}]$} & {$[\mathrm{MPa}]$} & [cycles] \\
B1_2_4 & 40.6 & 10.3 & 718 & 0.05 & 26 & 17.0 & 221000 & 308 & 228112 & $\mathrm{~T}_{\text {ADI }}$ \\
B1_5_2 & 40.4 & 10.0 & 667 & 0.05 & 24 & 16.3 & 195600 & 293 & 358504 & $\mathrm{~T}_{\text {ADI }}$ \\
B1_2_3 & 40.2 & 10.4 & 718 & 0.05 & 23 & 15.0 & 172500 & 240 & 455291 & $\mathrm{~T}_{\text {ADI }}$ \\
B1_5_4 & 40.5 & 10.0 & 675 & 0.05 & 21 & 17.2 & 180600 & 268 & 590166 & $\mathrm{~T}_{\text {ADI }}$ \\
B1_5_6 & 40.6 & 10.0 & 677 & 0.05 & 21.5 & 16.1 & 172538 & 255 & 625883 & $\mathrm{~T}_{\text {ADI }}$ \\
B1_5_5 & 40.5 & 10.1 & 682 & 0.05 & 21 & 15.2 & 159075 & 233 & 627827 & $\mathrm{~T}_{\text {ADI }}$ \\
B1_5_3 & 40.3 & 9.9 & 657 & 0.05 & 21 & 16.4 & 171675 & 261 & 974888 & $\mathrm{~T}_{\text {ADI }}$ \\
B1_5_1 & 40.5 & 9.9 & 662 & 0.05 & 20 & 15.0 & 150000 & 227 & 2000000 & run out \\
B1_2_6 & 40.2 & 10.1 & 677 & 0.05 & 20.5 & 16.0 & 163488 & 242 & 2000000 & run out \\
B1_5_1\# & 40.5 & 9.9 & 662 & 0.05 & 25 & 16.0 & 199375 & 301 & 261184 & $\mathrm{~T}_{\text {ADI }}$ \\
B1_2_6\# & 40.2 & 10.1 & 677 & 0.05 & 29 & 15.0 & 217500 & 321 & 103560 & $\mathrm{~T}_{\text {ADI }}$ \\
B1_6_1 & 40.1 & 10.1 & 682 & 0.05 & 27 & 14.7 & 198450 & 291 & 590273 & $\mathrm{~T}_{\text {ADI }}$ \\
B1_6_2 & 40 & 10 & 667 & 0.05 & 29 & 13.5 & 195750 & 294 & 331582 & $\mathrm{~T}_{\text {ADI }}$ \\
B1_6_3 & 40.45 & 10.1 & 688 & 0.05 & 26 & 17.5 & 227500 & 331 & 826913 & $\mathrm{~T}_{\text {steel }}$ \\
\hline
\end{tabular}

${ }^{\#}$ Specimen retested after run-out

${ }^{\circ} \Delta \sigma$ according to Eq. (2)

$* \mathrm{~T}_{\mathrm{ADI}}=$ toe at the ADI 1050 side, $\mathrm{T}_{\text {steel }}=$ toe at the $\mathrm{S} 355 \mathrm{~J} 2$ steel side 
Table 10 Fatigue test results obtained from full-penetration butt welded joints, flush ground, under pure axial loading with nominal load ratio $R=0.05$

\begin{tabular}{lllllllll}
\hline Specimen code & $W$ & $t$ & Gross section $A_{\mathrm{g}}$ & $R$ & $\Delta F$ & $\Delta \sigma^{\circ}$ & $N_{f}$ & Failure location* \\
\hline & {$[\mathrm{mm}]$} & {$[\mathrm{mm}]$} & {$\left[\mathrm{mm}^{2}\right]$} & & {$[\mathrm{kN}]$} & {$[\mathrm{MPa}]$} & {$[$ cycles] } \\
B2_4_3 & 40.8 & 7.0 & 284 & 0.05 & 85.1 & 300 & 1308257 & run out \\
B2_4_5 & 40.3 & 8.1 & 324 & 0.05 & 110.3 & 340 & 12950 & $\mathrm{I}_{\mathrm{ADI}}$ \\
B2_4_6 & 40.9 & 8.1 & 329 & 0.05 & 105.4 & 320 & 184873 & $\mathrm{I}_{\mathrm{ADI}}$ \\
B2_4_2 & 40.0 & 8.0 & 318 & 0.05 & 101.8 & 320 & 109630 & $\mathrm{I}_{\mathrm{ADI}}$ \\
B2_4_4 & 30.1 & 8.1 & 244 & 0.05 & 73.1 & 300 & 157445 & $\mathrm{I}_{\mathrm{ADI}}+\mathrm{WB}$ \\
B2_8_5 & 40.0 & 8.1 & 324 & 0.05 & 97.0 & 299 & 1764636 & $\mathrm{I}_{\mathrm{ADI}}$ \\
\hline
\end{tabular}

${ }^{\circ} \Delta \sigma$ according to Eq. (3)

$* \mathrm{I}_{\mathrm{ADI}}=$ interface between $\mathrm{ADI} 1050$ and weld bead, $\mathrm{WB}=$ crack traversing the weld bead

Table 11 Fatigue test results obtained from nlc fillet-welded transverse stiffener joints under four-point-bending loading with nominal load ratio $R=$ 0.05

\begin{tabular}{|c|c|c|c|c|c|c|c|c|c|c|}
\hline Specimen code & $W$ & $t$ & $W_{f}$ & $R$ & $\Delta F$ & $b$ & $\Delta M_{f}$ & $\Delta \sigma^{\circ}$ & $N_{f}$ & Failure location* \\
\hline & {$[\mathrm{mm}]$} & {$[\mathrm{mm}]$} & {$\left[\mathrm{mm}^{3}\right]$} & & {$[\mathrm{kN}]$} & {$[\mathrm{mm}]$} & {$[\mathrm{Nmm}]$} & {$[\mathrm{MPa}]$} & [cycles] & \\
\hline C_6_3 & 39.3 & 10.0 & 654 & 0.05 & 30.5 & 15.0 & 228750 & 350 & 42931 & $\mathrm{~T}_{\mathrm{ADI}}$ \\
\hline C_11 11 & 40.7 & 10.1 & 691 & 0.05 & 29.7 & 15.0 & 222750 & 322 & 782127 & $\mathrm{~T}_{\mathrm{ADI}}$ \\
\hline $\mathrm{C}_{-}^{-} 12-1$ & 40.3 & 10.1 & 678 & 0.05 & 39 & 15.0 & 292500 & 431 & 153004 & $\mathrm{~T}_{\mathrm{ADI}}$ \\
\hline C_- $7 \_1$ & 40.2 & 10.5 & 732 & 0.05 & 32 & 15.0 & 240000 & 328 & 175019 & $\mathrm{~T}_{\mathrm{ADI}}$ \\
\hline C_8_3 & 39.9 & 10.0 & 665 & 0.05 & 36 & 15.0 & 270000 & 406 & 175437 & $\mathrm{~T}_{\mathrm{ADI}}$ \\
\hline $\mathrm{C}_{-}^{-} 7_{-}^{-} 3$ & 40.2 & 10.2 & 690 & 0.05 & 30 & 15.0 & 225000 & 326 & 226568 & $\mathrm{~T}_{\mathrm{ADI}}$ \\
\hline C_5_- 1 & 40.0 & 10.6 & 749 & 0.05 & 36 & 15.0 & 270000 & 360 & 327322 & $\mathrm{~T}_{\mathrm{ADI}}$ \\
\hline C_9_3 & 40.7 & 10.0 & 678 & 0.05 & 29.5 & 15.0 & 221250 & 327 & 104687 & $\mathrm{~T}_{\mathrm{ADI}}$ \\
\hline C_10_2 & 40.1 & 10.2 & 689 & 0.05 & 42 & 15.0 & 315000 & 457 & 104527 & $\mathrm{~T}_{\mathrm{ADI}}$ \\
\hline C_8_2 & 40.2 & 10.05 & 677 & 0.05 & 44 & 15.0 & 330000 & 488 & 54270 & $\mathrm{~T}_{\mathrm{ADI}}$ \\
\hline C_-11_2 & 40.1 & 10.3 & 709 & 0.05 & 44 & 15.0 & 330000 & 465 & 90293 & $\mathrm{~T}_{\mathrm{ADI}}$ \\
\hline C_-12_3 & 40.5 & 10.2 & 702 & 0.05 & 29 & 15.0 & 217500 & 310 & 3375268 & $\mathrm{~T}_{\mathrm{ADI}}$ \\
\hline C_-10_1 & 40 & 10.1 & 680 & 0.05 & 29 & 15.0 & 217500 & 320 & 2000000 & run out \\
\hline C_- $8 \_-1$ & 40.3 & 10.05 & 678 & 0.05 & 26 & 15.0 & 195000 & 287 & 2000000 & run out \\
\hline C_5_2 & 39.7 & 10.25 & 695 & 0.05 & 29.5 & 15.0 & 221250 & 318 & 2000000 & run out \\
\hline C_8_1\# & 40.3 & 10.1 & 678 & 0.05 & 36 & 15.0 & 270000 & 398 & 82159 & $\mathrm{~T}_{\mathrm{ADI}}$ \\
\hline C_5_2\# & 39.7 & 10.3 & 695 & 0.05 & 38 & 15.0 & 285000 & 410 & 299261 & $\mathrm{~T}_{\mathrm{ADI}}$ \\
\hline
\end{tabular}

\# Specimen retested after run-out

${ }^{\circ} \Delta \sigma$ according to Eq. (2)

$* \mathrm{~T}_{\mathrm{ADI}}=$ toe at the ADI 1050 side

Table 12 Fatigue test results obtained from nlc fillet-welded transverse stiffener joints under four-point-bending loading with nominal load ratio $R=$ 0.5

\begin{tabular}{lllllllllll}
\hline Specimen code & $W$ & $t$ & $W_{f}$ & $R$ & $\Delta F$ & $b$ & $\Delta M_{f}$ & $\Delta \sigma^{\circ}$ & $N_{f}$ & Failure location* \\
\hline & {$[\mathrm{mm}]$} & {$[\mathrm{mm}]$} & {$\left[\mathrm{mm}^{3}\right]$} & & {$[\mathrm{kN}]$} & {$[\mathrm{mm}]$} & {$[\mathrm{Nmm}]$} & {$[\mathrm{MPa}]$} & {$[\mathrm{cycles}]$} \\
C_9_1 & 40.2 & 10.0 & 669 & 0.5 & 35 & 13.9 & 243250 & 364 & 52884 & $\mathrm{~T}_{\text {ADI }}$ \\
C_12_2 & 40.2 & 10.1 & 683 & 0.5 & 28 & 14.0 & 196000 & 287 & 587809 & $\mathrm{~T}_{\text {ADI }}$ \\
C_9_2 & 40.2 & 10.1 & 683 & 0.5 & 29.5 & 14.4 & 212400 & 311 & 212312 & $\mathrm{~T}_{\text {ADI }}$ \\
C_18_2 & 40 & 10 & 667 & 0.5 & 26 & 14.9 & 193700 & 291 & 179361 & $\mathrm{~T}_{\text {ADI }}$ \\
C_18_3 & 39.9 & 10 & 665 & 0.5 & 26 & 16.2 & 210600 & 317 & 109229 & $\mathrm{~T}_{\text {ADI }}$ \\
C_16_3 & 40 & 10 & 667 & 0.5 & 22 & 16.2 & 177650 & 266 & 110198 & $\mathrm{~T}_{\text {ADI }}$ \\
C_17_1 & 40 & 10 & 667 & 0.5 & 20 & 14.9 & 148500 & 223 & 1691834 & run out \\
C_13_3 & 39.9 & 10 & 665 & 0.5 & 24 & 14.8 & 177600 & 267 & 107812 & $\mathrm{~T}_{\text {ADI }}$ \\
C_16_2 & 39.5 & 10 & 658 & 0.5 & 27 & 13.8 & 186300 & 283 & 242797 & $\mathrm{~T}_{\text {ADI }}$ \\
\hline
\end{tabular}

${ }^{\circ} \Delta \sigma$ according to Eq. (2)

$* \mathrm{~T}_{\mathrm{ADI}}=$ toe at the $\mathrm{ADI} 1050$ side 
Fig. 21 Experimental results of axial fatigue tests performed on partial-penetration butt welded joints; nominal axial stress range evaluated in the weld throat area

Fig. 22 Experimental results of four-point-bending fatigue tests performed on full-penetration butt welded joints; nominal bending stress range evaluated in the cross-section area
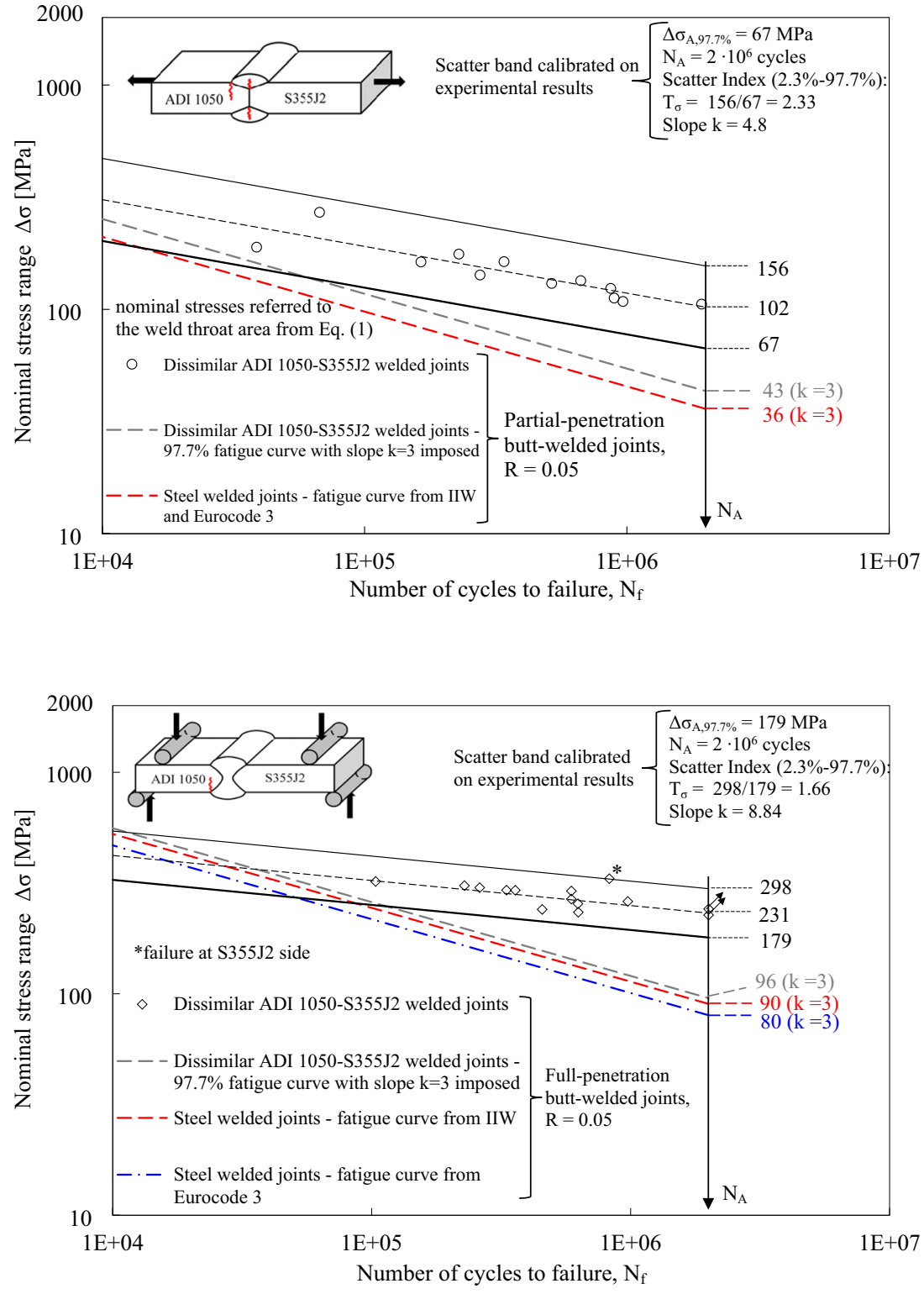

Fig. 23 Experimental results of pure axial fatigue tests performed on full-penetration butt welded joints, flush ground; nominal axial stress range evaluated in the cross-section area

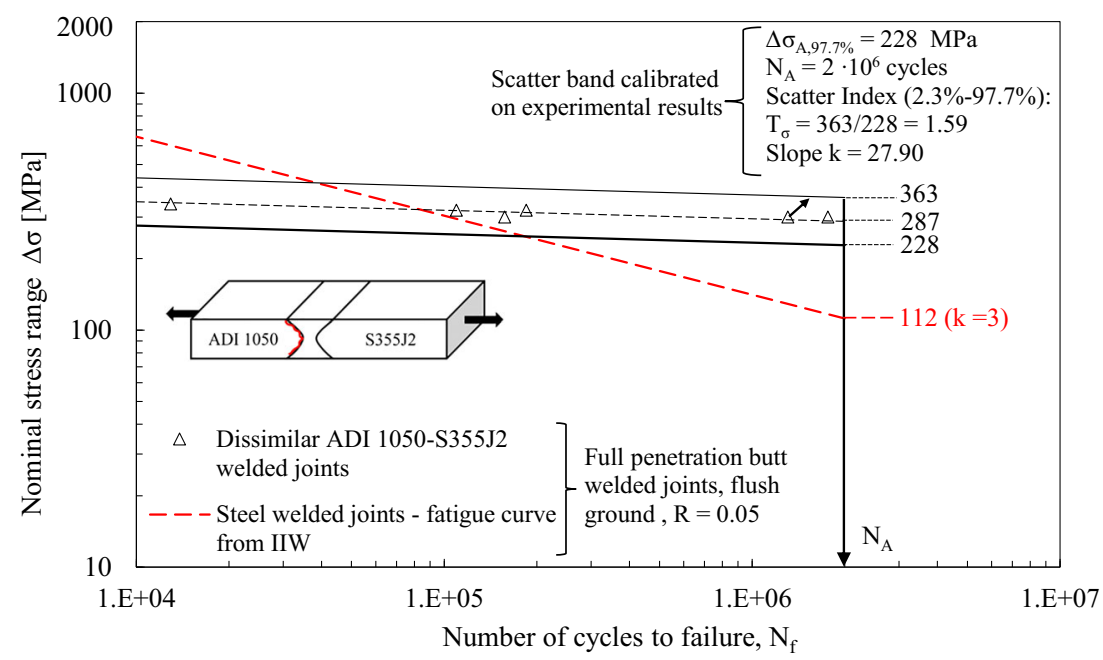


Fig. 24 Experimental results of four-point-bending fatigue tests performed on nlc fillet-welded transverse stiffener joints; nominal bending stress range evaluated in the cross-section area. Experimental results obtained by adopting a nominal load ratio a $R$ $=0.05$, $\mathbf{b} R=0.5$ and $\mathbf{c} R=0.05$ and 0.5
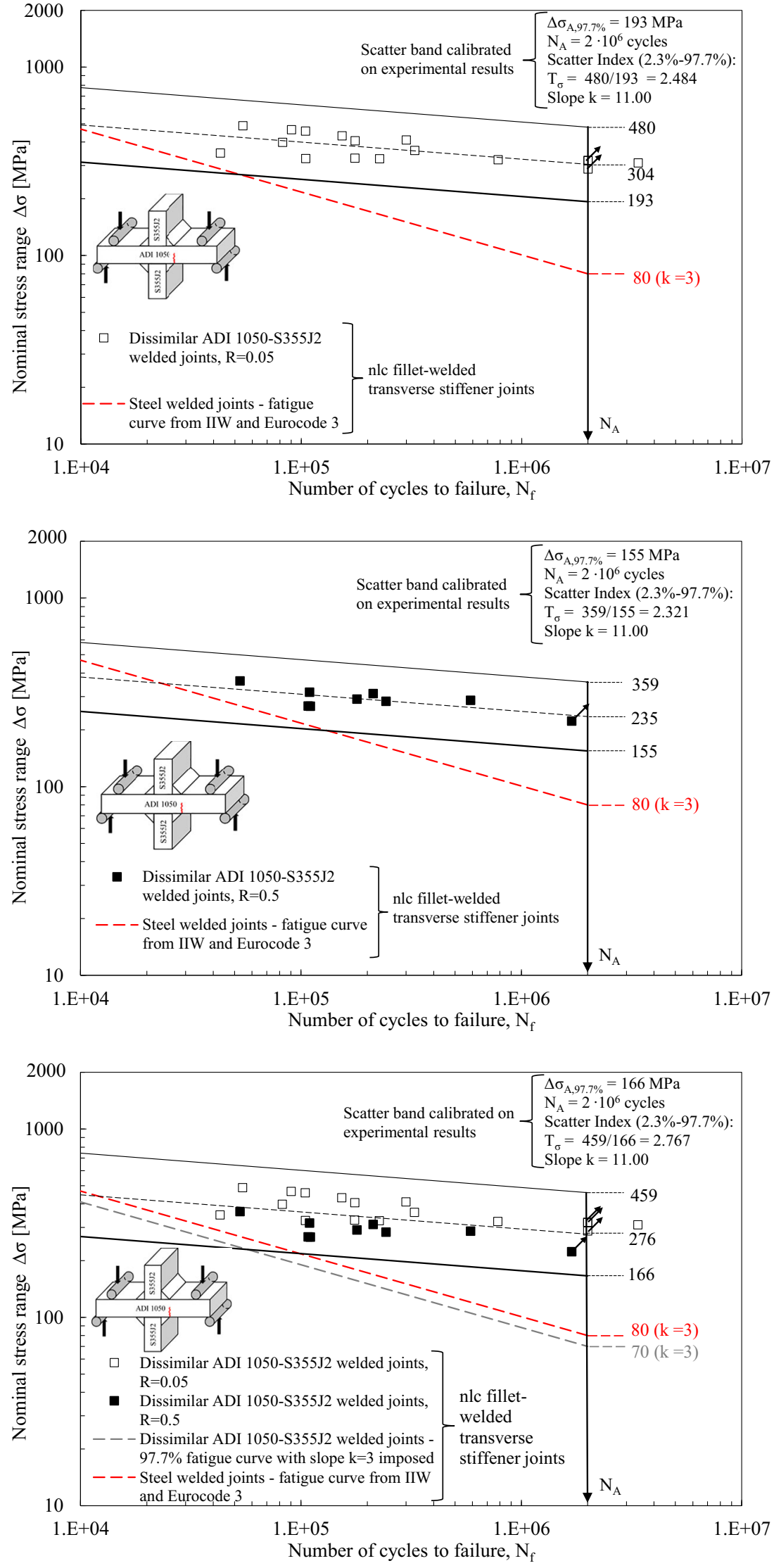
Table 13 Summary of experimental fatigue results

\begin{tabular}{|c|c|c|c|c|c|c|c|}
\hline Test series & Welded joint geometry & $\begin{array}{l}\text { Testing } \\
\text { condition }\end{array}$ & Load $^{\#}$ & Nominal load ratio $\mathrm{R}$ & $\Delta \sigma_{\mathrm{A}}^{\circ}[\mathrm{MPa}]$ & $\mathrm{k}$ & $\mathrm{T}_{\sigma}$ \\
\hline A & Partial-penetration butt welded joints & AW & $\mathrm{Ax}$ & 0.05 & 67 & 4.8 & 2.33 \\
\hline B1 & Full-penetration butt welded joints & & $4 \mathrm{~PB}$ & 0.05 & 179 & 8.84 & 1.66 \\
\hline B2 & Full-penetration butt welded joints, flush ground & & $\mathrm{Ax}$ & 0.05 & 228 & 27.90 & 1.59 \\
\hline $\mathrm{C}$ & nlc fillet-welded transverse stiffener joints & & $4 \mathrm{~PB}$ & $\begin{array}{l}0.05 \\
0.5\end{array}$ & $\begin{array}{l}193 \\
155\end{array}$ & 11 & $\begin{array}{l}2.48 \\
2.32\end{array}$ \\
\hline
\end{tabular}

$* \mathrm{AW}=$ as welded

${ }^{\#} \mathrm{Ax}=$ axial load, $4 \mathrm{~PB}=$ four-point bending load

${ }^{\circ}$ Endurable stress range referred to a survival probability of $97.7 \%$ and $N_{\mathrm{A}}=2$ million loading cycles

IIW Recommendations for the corresponding homogeneous steel joints.

- Full-penetration butt welded joints have been fatigue tested under four-point-bending loading with $R=0.05$ and showed fatigue crack initiation at the weld toe at the ADI side. They exhibited an endurable stress range of $179 \mathrm{MPa}$ (P.s. $97.7 \%$ and $N=2 \cdot 10^{6}$ cycles) to compare with FAT $80 \mathrm{MPa}$ and $90 \mathrm{MPa}$ of Eurocode 3 and IIW Recommendations, respectively, for the corresponding homogeneous steel joints.

- Full-penetration butt welded joints, flush ground, have been fatigue tested under pure axial loading with $R=$ 0.05 and showed fatigue crack initiation at the interface between the plate and the weld bead at the ADI side, i.e. in a region where considerable amounts of ledeburite form during welding. They exhibited an endurable stress range of $228 \mathrm{MPa}$ (P.s. $97.7 \%$ and $N=$ $2 \cdot 10^{6}$ cycles) to compare with FAT $112 \mathrm{MPa}$ of Eurocode 3 and IIW Recommendations for the corresponding homogeneous steel joints.

- Non-load-carrying fillet-welded transverse stiffener joints have been fatigue tested under four-point-bending loading with $R=0.05$ and 0.5 and showed fatigue crack initiation at the weld toe at the ADI side. They exhibited an endurable stress range of $193 \mathrm{MPa}$ for $R=0.05$ and $155 \mathrm{MPa}$ for $R=0.5$ (P.s. $97.7 \%$ and $N=2 \cdot 10^{6}$ cycles) to compare with FAT $80 \mathrm{MPa}$ of Eurocode 3 and IIW Recommendations for the corresponding homogeneous steel joints.

- The fatigue performances of austempered ductile iron-tosteel dissimilar arc-welded joints have been observed to be higher than those suggested by International Standards and Recommendations for the corresponding steel welded joints. Accordingly, the fatigue strength assessment of ADI-to-steel dissimilar arc-welded joints could be performed on the safe side by applying the nominal stress approach proposed by International Standards and Recommendations for the corresponding steel welded joints.
Funding Open Access funding provided by Università degli Studi di Padova.

Open Access This article is licensed under a Creative Commons Attribution 4.0 International License, which permits use, sharing, adaptation, distribution and reproduction in any medium or format, as long as you give appropriate credit to the original author(s) and the source, provide a link to the Creative Commons licence, and indicate if changes were made. The images or other third party material in this article are included in the article's Creative Commons licence, unless indicated otherwise in a credit line to the material. If material is not included in the article's Creative Commons licence and your intended use is not permitted by statutory regulation or exceeds the permitted use, you will need to obtain permission directly from the copyright holder. To view a copy of this licence, visit http://creativecommons.org/licenses/by/4.0/.

\section{References}

1. Martinsen K, Hu SJ, Carlson BE (2015) Joining of dissimilar materials. CIRP Ann 64:679-699. https://doi.org/10.1016/j.cirp.2015. 05.006

2. Paventhan R, Lakshminarayanan PR, Balasubramanian V (2011) Fatigue behaviour of friction welded medium carbon steel and austenitic stainless steel dissimilar joints. Mater Des 32:1888-1894. https://doi.org/10.1016/j.matdes.2010.12.011

3. Mohammadzadeh Polami S, Häfele P, Rethmeier M, Schmid A (2015) Study on fatigue behavior of dissimilar materials and different methods of friction-welded joints for drive pinion in trucks. Weld World 59:917-926. https://doi.org/10.1007/s40194-0150258-8

4. Infante V, Braga DFO, Duarte F, Moreira PMG, de Freitas M, de Castro PMST (2016) Study of the fatigue behaviour of dissimilar aluminium joints produced by friction stir welding. Int J Fatigue 82 : 310-316. https://doi.org/10.1016/j.ijfatigue.2015.06.020

5. Eslami N, Harms A, Henke B, Fricke A, Böhm S (2019) Electrical and mechanical properties of friction stir welded $\mathrm{Al}-\mathrm{Cu}$ butt joints. Weld World 63:903-911. https://doi.org/10.1007/s40194-01900719-y

6. Okamura H, Aota K (2004) Joining of dissimilar materials with friction stir welding. Weld Int 18:852-860. https://doi.org/10. 1533/wint.2004.3344

7. Uzun H, Dalle Donne C, Argagnotto A, Ghidini T, Gambaro C (2005) Friction stir welding of dissimilar Al 6013-T4 To X5CrNi18-10 stainless steel. Mater Des 26:41-46. https://doi.org/ 10.1016/j.matdes.2004.04.002 
8. Figner G, Vallant R, Weinberger T, Enzinger N, Schröttner H, Paśič H (2009) Friction stir spot welds between aluminium and steel automotive sheets: influence of welding parameters on mechanical properties and microstructure. Weld World 53:R13-R23. https://doi.org/10.1007/BF03266697

9. Taban E, Gould JE, Lippold JC (2010) Dissimilar friction welding of 6061-T6 aluminum and AISI 1018 steel: properties and microstructural characterization. Mater Des 31:2305-2311. https://doi. org/10.1016/J.MATDES.2009.12.010

10. Roberts DI, Ryder RH, Viswanathan R (1985) Performance of dissimilar welds in service. J Press Vessel Technol 107:247-254. https://doi.org/10.1115/1.3264443

11. Bettahar K, Bouabdallah M, Badji R, Gaceb M, Kahloun C, Bacroix B (2015) Microstructure and mechanical behavior in dissimilar 13Cr/2205 stainless steel welded pipes. Mater Des 85:221229. https://doi.org/10.1016/j.matdes.2015.07.017

12. Zhang Q, Zhang J, Zhao P, Huang Y, Yu Z, Fang X (2016) Lowcycle fatigue behaviors of a new type of $10 \% \mathrm{Cr}$ martensitic steel and welded joint with Ni-based weld metal. Int J Fatigue 88:78-87. https://doi.org/10.1016/j.jfatigue.2016.03.003

13. Kumar S, Singh PK, Karn KN, Bhasin V (2017) Experimental investigation of local tensile and fracture resistance behaviour of dissimilar metal weld joint: SA508 Gr.3 Cl.1 and SA312 Type 304LN. Fatigue Fract Eng Mater Struct 40:190-206. https://doi. org/10.1111/ffe.12484

14. Zhang W-C, Zhu M-L, Wang K, Xuan F-Z (2018) Failure mechanisms and design of dissimilar welds of $9 \% \mathrm{Cr}$ and $\mathrm{CrMoV}$ steels up to very high cycle fatigue regime. Int J Fatigue 113:367-376. https://doi.org/10.1016/j.ijfatigue.2018.04.032

15. Zhang W, Jiang W, Zhao X, Tu ST (2018) Fatigue life of a dissimilar welded joint considering the weld residual stress: experimental and finite element simulation. Int J Fatigue 109:182-190. https:// doi.org/10.1016/j.ijfatigue.2018.01.002

16. Al Zamzami I, Davison B, Susmel L (2019) Nominal and local stress quantities to design aluminium-to-steel thin welded joints against fatigue. Int J Fatigue 123:279-295. https://doi.org/10. 1016/J.IJFATIGUE.2019.02.018

17. Parkes D, Xu W, Westerbaan D, Nayak SS, Zhou Y, Goodwin F, Bhole S, Chen DL (2013) Microstructure and fatigue properties of fiber laser welded dissimilar joints between high strength low alloy and dual-phase steels. Mater Des 51:665-675. https://doi.org/10. 1016/j.matdes.2013.04.076

18. Katayama S (2004) Laser welding of aluminium alloys and dissimilar metals. Weld Int 18:618-625. https://doi.org/10.1533/wint. 2004.3315

19. Sun M, Behravesh SB, Wu L, Zhou Y, Jahed H (2017) Fatigue behaviour of dissimilar Al 5052 and Mg AZ31 resistance spot welds with Sn-coated steel interlayer. Fatigue Fract Eng Mater Struct 40:1048-1058. https://doi.org/10.1111/ffe.12563

20. Rao HM, Kang J, Shi L, Sigler DR, Carlson BE (2018) Effect of specimen configuration on fatigue properties of dissimilar aluminum to steel resistance spot welds. Int J Fatigue 116:13-21. https:// doi.org/10.1016/j.ijfatigue.2018.06.009

21. Geng H, Sun L, Li G, Cui J, Huang L, Xu Z (2019) Fatigue fracture properties of magnetic pulse welded dissimilar Al-Fe lap joints. Int J Fatigue 121:146-154. https://doi.org/10.1016/j.ijfatigue.2018.12. 027

22. Eurocode 3: Design of steel structures - part 1-9: Fatigue. CEN; 2005.

23. Eurocode 9: Design of aluminium structures - part 1-3: structures susceptible to fatigue. CEN; 2011.

24. Hobbacher AF. Recommendations for fatigue design of welded joints and components. IIW Collection. Springer International Publishing; 2016. doi:https://doi.org/10.1007/978-3-319-23757-2.

Publisher's note Springer Nature remains neutral with regard to jurisdictional claims in published maps and institutional affiliations. 